Krzysztof Łagojda

Wrocław

\title{
Rola aparatu represji w kontrolowaniu granicy państwowej na przykładzie ziemi kłodzkiej w latach 1949-1956
}

\begin{abstract}
A b s trakt: Głównym celem artykułu było przeanalizowanie działań aparatu represji na płaszczyźnie ochrony granicy, inwigilacji i walki z osobami, które nosiły się z zamiarem lub próbowały ją nielegalnie przekroczyć. Autor próbował odpowiedzieć na pytanie, czy jej zabezpieczenie było dla powiatowych urzędów sprawą priorytetową oraz jak wywiązywały się z tego zadania.
\end{abstract}

Słowa kluczowe: granica, aparat represji, agentura, WOP.

Abstract: The main purpose of the article is an analysis of actions undertaken by the apparatus of repression vis-à-vis the protection of borders, surveillance, and struggle against people who wanted or tried to illegally cross the border. The author sought to answer the question whether it was the matter of top priority for district authorities to secure the border, and how did they fulfil this goal.

Keyw ords: frontier, repression apparatus, agents, Border Guard.

\section{Wstęp}

W języku polskim słowo „granica” było i jest używane w wielu kontekstach oraz znaczeniach, a świadczą o tym chociażby powieść psychologiczna Zofii Nałkowskiej i liczne interpretacje tytułu. Sięgając do Encyklopedii popularnej $P W N$ możemy znaleźć kilka haseł dotyczących tego zagadnienia. Większość z nich odnosi się do pojęć matematycznych, takich jak: „granica funkcji”, „granica całkowania”, ale dowiemy się także, czym jest „granica wiecznego śniegu”. Oczywiście najbardziej powszechne znaczenie tego pojęcia dotyczy 
granicy państwowej. Jest to „Powierzchnia pionowa przechodząca przez linię graniczna oddzielajaca terytorium, podziemie i obszar powietrzny jednego państwa od innych państw lub morza pełnego. Rozróżnia się granice lądowe i wodne, naturalne i sztuczne"1. Z kolei Stownik języka polskiego określa granicę linią zamykająca lub oddzielającą jedno terytorium państwa od innych ${ }^{2}$. W kontekście lat 1949-1956, które obejmuje ten artykuł, określenie granicy jako linii zamykającej wydaje się nader trafne.

Regulacje dotyczące granicy z podziałem na odpowiednie strefy, które obowiazywały także w okresie stalinowskim, po raz pierwszy zawarto w Rozporządzeniu Prezydenta Rzeczypospolitej z dnia 23 XII 1927 r. o granicach Państwa ${ }^{3}$. Bezpieka, oprócz definicji linii granicznej, bazując na wspomnianym rozporządzeniu, wyróżniała także: teren pogranicza, dzieląc go na pas drogi granicznej, strefę nadgraniczną oraz pas graniczny. Pasem drogi granicznej określano obszar przyległy do linii granicznej o szerokości do $15 \mathrm{~m}$. Na szerokości od 2 do $6 \mathrm{~km}$ rozciagała się strefa nadgraniczna. Wjazd do niej był możliwy jedynie za okazaniem specjalnych przepustek. Także ludność, która zamieszkiwała te tereny, została zobowiązana do przestrzegania szeregu dodatkowych przepisów, takich jak zakaz hodowania dużych psów i gołębi czy posiadania aparatów fotograficznych. Z kolei pas graniczny krótko i lakonicznie określano obszarem przyległym do linii granicznej o szerokości $30 \mathrm{~km}^{4}$. W przypadku województwa wrocławskiego ustalenie pasa drogi granicznej oraz zasięgu strefy nadgranicznej zapadło decyzją wojewody 6 XI 1947 r. ${ }^{5}$ Wyróżniony podział miał na celu lepszą ochronę granicy państwowej. Dlatego też na obszarze całego pasa granicznego Wojska Ochrony Pogranicza (WOP) miały prawo zakładać posterunki, przeprowadzać rewizję i sprawdzać dokumenty u osób podejrzanych.

Rozbudowano system zasieków z drutu kolczastego, strażnic, czujek rakietowych nie tylko na granicy wschodniej z ZSRS, ale także na zachodniej. Na odcinku $470 \mathrm{~km}$ postawiono płot i 316 wież strażniczych. $100 \mathrm{~m}$ od granicy wycinano drzewa i krzewy, których wykarczowano ponad 3 tys. ha. Powstał także tzw. pas kontrolny, czyli obszar zaoranej ziemi, regularnie co noc bronowany, na którym po przejściu człowieka lub zwierzęcia pozostawał ślad. W ten sposób oddziały WOP wiedziały, czy ktoś pod osłoną nocy przekroczył granicę. Na dodatek liczne oddziały WOP z psami tropiacymi patrolowały

\footnotetext{
${ }^{1}$ Encyklopedia popularna PWN, wyd. 21 zm. i uzup., Warszawa 1991, s. 270.

2 Stownik języka polskiego, oprac. E. Sobol, Warszawa 2005, s. 245.

${ }^{3}$ Dz.U. 1927, nr 117, poz. 996, s. 1660-1663.

${ }^{4}$ Archiwum Instytutu Pamięci Narodowej we Wrocławiu (dalej: AIPN Wr), sygn. 053/3374, Ochrona granicy przed przenikaniem agentów obcego wywiadu, czerwiec 1956 r., k. 3-4.

${ }^{5}$ Archiwum Państwowe we Wrocławiu (dalej: APWr), Prezydium Wojewódzkiej Rady Narodowej we Wrocławiu (dalej: PWRN), sygn. XIII/385, Rozporządzenie wojewody wrocławskiego w sprawie ustalenia pasa drogi granicznej i strefy nadgranicznej na obszarze województwa wrocławskiego, 6 XI 1947 r., k. 95-112.
} 
granicę. Także w ZSRS w 1948 r. doszło do uszczelnienia nowej granicy zachodniej, a - jak zauważył Dariusz Stola - „zbieżność z późniejszym o parę miesięcy podobnym przyspieszeniem [w zamknięciu granicy - K.Ł.] w Polsce była chyba nieprzypadkowa" . Polska stała się jednym wielkim obozem koncentracyjnym otoczonym drutem kolczastym, ale tak jak w nim, także w Polsce „ludowej” okresu stalinowskiego, ucieczki były możliwe.

Główny cel tekstu stanowiły przeanalizowanie działań aparatu represji na płaszczyźnie zabezpieczenia granicy, inwigilacji i walki z osobami, które nosiły się z zamiarem lub próbowały ja nielegalnie przekroczyć, oraz odpowiedź na pytanie, czy jej zabezpieczenie było dla powiatowych urzędów sprawa priorytetowa. Analizie poddałem m.in. dokumenty dotyczace kontrwywiadowczej charakterystyki województwa wrocławskiego oraz poszczególnych powiatów, miesięczne sprawozdania szefa Wojewódzkiego Urzędu Bezpieczeństwa Publicznego (WUBP), sprawozdania i analizy pracy Wydziału I WUBP zajmującego się kontrwywiadem (późniejszy Wydział II WUdsBP), wykazy agentury i doniesienia wykorzystywane do zabezpieczenia granic, protokoły przesłuchań, sentencje wyroków sądów powiatowych i grodzkich, akta spraw rozpatrywanych przez Komisję Specjalną do Walki z Nadużyciami i Szkodnictwem Gospodarczym oraz sprawozdania roczne, kwartalne i miesięczne trzech powiatowych urzędów bezpieczeństwa publicznego (PUBP)/PUdsBP ziemi kłodzkiej: w Kłodzku, Bystrzycy i Nowej Rudzie w latach 1949-1956 ${ }^{8}$.

W tekście został pominięty aspekt, który był jednym z czynników powodujacych ucieczki z kraju, a mianowicie restrykcyjna polityka paszportowa państwa, szczegółowo przedstawiona w znakomitej pracy D. Stoli Kraj bez wyjścia?99

Kilku słów wyjaśnienia wymaga cezura czasowa zaproponowana w tekście, bowiem nie nawiązuje ona bynajmniej tylko do okresu forsownej stalinizacji Polski i szeregu zmian w unifikacji i ideologizacji wszystkich dziedzin życia społecznego, gospodarczego i politycznego kraju. Uznanie roku 1949 jako początkowej cezury nie znaczy także, że dopiero od tego momentu władze

${ }^{6}$ Odnotowane zostały przypadki smarowania podeszwy butów chlorem w celu uniemożliwienia podjęcia tropu przez psa. Zob. AIPN Wr, sygn. 053/273, Raport Powiatowego Urzędu Bezpieczeństwa Publicznego w Bystrzycy Kłodzkiej za okres od dnia 30 XI do 31 XII 1953 r., 3 I 1954 r., k. 178.

${ }^{7}$ D. Stola, Kraj bez wyjścia? Migracje z Polski 1949-1989, Warszawa 2012, s. 41.

${ }^{8}$ Powiat noworudzki został wydzielony z powiatu kłodzkiego na podstawie Rozporządzenia Rady Ministrów z 11 VIII 1954 r. Zob. Dz.U. 1954, nr 49, poz. 249, s. 415. PUBP w Nowej Rudzie powstał 1 I 1955 r. Natomiast reorganizacja struktur WUdsBP i poszczególnych powiatowych urzędów trwała od grudnia 1954 do kwietnia $1955 \mathrm{r}$.

${ }^{9} \mathrm{Z}$ innych tekstów autora warto zauważyć także: D. Stola, Zamknięcie Polski. Zniesienie swobody wyjazdu i uszczelnienie granic w latach 40. $i$ 50., w: PRL. Trwanie i zmiana, red. D. Stola, M. Zaremba, Warszawa 2003, s. 159-186; D. Stola, O paradoksie masowej emigracji z państwa zamkniętego: wyjazdy do Niemiec $w$ pierwszej połowie lat pięćdziesiatych, w: Wtadza a społeczeństwo w PRL. Studia historyczne, red. A. Friszke, Warszawa 2003, s. 55-75. 
komunistyczne zaczęły przywiązywać uwagę do ochrony granic. Już 29 IX 1946 r. została zatwierdzona instrukcja „o wzajemnej współpracy organów wywiadowczych WOP i Urzędu Bezpieczeństwa”, podpisana przez ministra bezpieczeństwa publicznego i naczelnego dowódcę Wojska Polskiego (WP), która regulowała zasady współpracy i wspólnych działań na granicy ${ }^{10}$. Z dniem 1 I 1949 r. WOP, utworzone i działające już w 1945 r., zostały podporządkowane Ministerstwu Bezpieczeństwa Publicznego (MBP). Doszło także do zaostrzenia i tak już rygorystycznej polityki wyjazdowej oraz zablokowania przez władze komunistyczne innych możliwości opuszczenia kraju. W specjalnej rezolucji z 24 II 1949 r. Sekretariat Komitetu Centralnego PZPR nakazywał organom represji: „Uszczelnić granice Rzeczypospolitej, szczególnie morską i zachodnia, utrudnić przenikanie przez nią agentów i łączników obcego wywiadu i ośrodków reakcyjnych"11. Miesiąc później minister bezpieczeństwa publicznego Stanisław Radkiewicz w referacie wygłoszonym podczas narady aktywu ministerstwa, odnosząc się do włączenia WOP w struktury MBP, stwierdził, iż jest to „przełom w podejściu do ochrony granicy i do pracy operacyjnej na pograniczu" 12 . Cezura roku 1956 odnosiła się oczywiście do procesu destalinizacji, ale wiązła się przede wszystkim z powolnym rozpadem i likwidacją najpierw struktur MBP na podstawie Dekretu Rady Państwa z 7 XII 1954 r. ${ }^{13}$, a później jego następcy, czyli Komitetu ds. Bezpieczeństwa Publicznego (KdsBP) w 1956 r. $^{14}$

Archiwalia dotyczące WOP, przechowywane wcześniej w Archiwum Straży Granicznej w Szczecinie (ASG), za lata 1949-1954 (kiedy WOP podlegały bezpośrednio MBP), zostały przekazane do Archiwum Instytutu Pamięci Narodowej. Korzystając z kwerendy przeprowadzonej w ASG, artykuł został nieznacznie uzupełniony o dokumenty wytworzone przez WOP z lat 1955-1956, kiedy ten podlegał już Ministerstwu Spraw Wewnętrznych (MSW) ${ }^{15}$. Historia tych wojsk w Polsce stanowiła już przedmiot wielu badań ${ }^{16}$. Nawiąując do

${ }^{10}$ Ł. Grabowski, M. Maruszak, Zarys struktur oraz zadania Zwiadu Wojsk Ochrony Pogranicza i Kontroli Ruchu Granicznego w latach 1945-1991, „Pamięć i Sprawiedliwość” 2012, nr 2 (20), s. 306.

${ }^{11}$ Rezolucja Sekretariatu KC PZPR w sprawie pracy organów bezpieczeństwa, przyjęta na posiedzeniu w dniu 24 lutego 1949 r., w: Aparat bezpieczeństwa w latach 1944-1956. Taktyka, strategia, metody, cz. 2: Lata 1948-1949, oprac. A. Paczkowski, Warszawa 1996, s. 20.

12 Materiaty narady aktywu MBP $w$ dniach 23-25 marca 1949, w: Aparat bezpieczeństwa..., s. 132; A. Garlicki, Z tajnych archiwów, Warszawa 1993, s. 102.

${ }^{13}$ Dz.U. 1954, nr 54, poz. 269, s. 441.

${ }^{14}$ Dz.U. 1956, nr 54, poz. 241, s. 445.

15 Formowanie jednostki WOP na ziemi kłodzkiej zakończono pod koniec września 1945 r. W latach 1945-1989 na terenach tych (z siedzibą w Kłodzku) stacjonowały: 11 Oddział Ochrony Pogranicza (1945-1946), 11 Wrocławski Oddział WOP (1946-1948), 23 Brygada Ochrony Pogranicza (1948-1950), 5 Brygada WOP (1950-1958) oraz Sudecka Brygada WOP (1958-1989).

${ }^{16}$ Pionierem badań nad historią WOP był Henryk Dominiczak, który w okresie stalinowskim służył w tej jednostce. Choć jego prace powstały jeszcze w okresie cenzury komunistycznej 
tytułu artykułu, trzeba jednak wyraźnie zaznaczyć, że celem głównej analizy jest działalność Urzędu Bezpieczeństwa (UB) jako organu decyzyjnego i odpowiedzialnego za kontrolę granic.

\section{Kontrwywiadowcza charakterystyka terenów granicznych}

Dla UB wstępne rozpoznanie kontrolowanego terenu stanowiło priorytetowa kwestię. Było to wyraźnie zauważalne w dokumentach bezpieki województwa wrocławskiego. Wszystkie powiaty graniczne w 1949 r. zostały poddane szczegółowej analizie pod kątem położenia, długości granicy, oceny zalesienia i górzystości. Dla przykładu powiat Żary opisywano jako leżący „na styku granicy województwa poznańskiego i granicy RP na północnym zachodzie. Długość granicy tegoż powiatu wynosi $70 \mathrm{~km}$. Jest to granica naturalna rzeka Nysa, która jest łatwa do przejścia ponieważ wysokość jej wód sięga od 0,40 do $1 \mathrm{~m}$. Ponadto, strefa przygraniczna jest gęsto zalesiona"17. Ocena ta wskazywała łatwość przekroczenia granicy. Powiaty o długiej granicy z obcymi państwami, mocno zalesione lub położone w górzystym rejonie oraz posiadające nieliczne punkty kontroli granicznej, były w oczach aparatu szczególnie narażone na nielegalne przekraczanie granicy czy też „przenikania elementów obcego wywiadu"18. W 1949 r. w województwie wrocławskim znajdowało się 10 powiatów granicznych, a łączna długość granicy z obcymi państwami została oszacowana na blisko $535 \mathrm{~km}$. Oprócz wspomnianego już powiatu żarskiego, który graniczył wówczas na odcinku $70 \mathrm{~km}$ z sowiecką

i skażone są osobistym stosunkiem do tej formacji, nadal przedstawiają pewna wartość. Zob. H. Dominiczak, Wojska Ochrony Pogranicza w latach 1945-1948, Warszawa 1971; idem, Powstanie i rozwój organizacyjny Wojsk Ochrony Pogranicza w latach 1945-1983, Warszawa 1984; idem, Zarys historii Wojsk Ochrony Pogranicza 1945-1985, Warszawa 1985. O granicach Polski na przestrzeni dziejów autor pisze w: Granice państwa i ich ochrona na przestrzeni dziejów 966-1996, Warszawa 1997; Z. Jackiewicz, Wojska Ochrony Pogranicza (1945-1991). Krótki informator historyczny, Kętrzyn 1998; J.R. Prochwicz, Wojska Ochrony Pogranicza 1945-1965. Wybrane problemy, Piotrków Trybunalski 2011. Ta ostatnia praca spotkała się z poważną i słuszną krytyką historyków, zob. rec. P. Skubisz, Jerzy Ryszard Prochwicz, Wojska Ochrony Pogranicza 1945-1965. Wybrane problemy, Piotrków Trybunalski 2011, „Aparat Represji w Polsce Ludowej 1944-1989” 2013, nr 11, s. 403-417. Nie sposób tutaj wymienić także bardzo licznych artykułów naukowych, które poruszały tematykę powstania, działalności i struktur WOP.

17 AIPN Wr, sygn. 053/624 t. 3, Kontrwywiadowcza charakterystyka województwa wrocławskiego na dzień 5 III 1949 r., k. 1.

18 Warto nadmienić, że z powiatów granicznych województwa wrocławskiego tylko nieliczne doczekały się analizy dotyczącej działalności aparatu represji na odcinku kontroli granicy. Najczęściej temat ten był opisywany w krótkich fragmentach monografii odnoszących się do powiatowych urzędów bezpieczeństwa, a nie w postaci osobnych artykułów. Zob. R. Klementowski, Zgorzelecka bezpieka 1945-1990, Wrocław 2014, s. 151-159; idem, Urzad Bezpieczeństwa w powiecie Lwówek Ślaski (1945-1956), Wrocław 2006, s. 149-161. 
strefą okupacyjną Niemiec ${ }^{19}$, były to powiaty: zgorzelecki (130 km), lubański (54,5 km), lwówecki (12km), jeleniogórski (52 km), kamiennogórski (42km), wałbrzyski $(35 \mathrm{~km})$, kłodzki $(80 \mathrm{~km})$, bystrzycki $(50 \mathrm{~km})$, ząbkowicki $(8 \mathrm{~km})$. Specyficzny i trudny do jednoznacznej oceny wydaje się tutaj przypadek powiatu żagańskiego, bowiem na małym odcinku styka się on ze strefa nadgraniczna. W charakterystyce bezpieki czytamy, że „z zachodu graniczy z powiatem Żary oraz wąskim klinem wrzyna się w strefę przygraniczna i jest $3 \mathrm{~km}$ odległy od granicy niemieckiej (strefa radziecka)"20. W raporcie sytuacyjnym z marca 1949 r. Sekcji VI Wydziału I WUBP widnieje informacja o 11 powiatach położonych przy granicy, co może wskazywać, że w oczach resortu powiat żagański również był powiatem granicznym ${ }^{21}$.

Powiat zgorzelecki posiadał najdłuższą granicę z obcym państwem i jako jedyny graniczył nie tylko z Czechosłowacją $(45 \mathrm{~km})$, ale także z sowiecka strefą okupacyjna Niemiec $(85 \mathrm{~km})$, a od października 1949 r. z NRD ${ }^{22}$. Wymienione powyżej wartości dają łączną długość 533,5 km granicy województwa wrocławskiego z obcymi państwami. Nie są to niestety jedyne rozbieżności, $\mathrm{z}$ jakimi spotykamy się $\mathrm{w}$ tej charakterystyce. Różnice dotyczą powiatów bystrzyckiego i jeleniogórskiego. WUBP określił długość granicy powiatu bystrzyckiego na 50, a jeleniogórskiego - na $52 \mathrm{~km}^{23}$. PUBP w Bystrzycy w licznych raportach sprawozdawczych i kontrwywiadowczej ocenie powiatu szacował długość granicy z Czechosłowacją na $82 \mathrm{~km}^{24}$. To samo dotyczy Jeleniej Góry. Przyglądając się szczegółowej mapie województwa wrocławskiego z podziałem na powiaty, należy stwierdzić, że ocena powiatowego UB wydaje się właściwsza. Dodając zatem te różnice, $32 \mathrm{~km}$ do granicy powiatu bystrzyckiego i $30 \mathrm{~km}$ do jeleniogórskiego, łączna długość linii demarkacyjnej województwa wrocławskiego z dwoma państwami powinna wynieść $595,5 \mathrm{~km}$.

Po przemianach administracyjnych Polski w 1950 r., utworzono trzy dodatkowe województwa: opolskie, zielonogórskie i koszalińskie ${ }^{25}$. Powiat

${ }^{19}$ Charakterystyka sporządzona została w marcu 1949 r., NRD powstało dopiero w październiku.

${ }^{20}$ AIPN Wr, sygn. 053/624 t. 3, Kontrwywiadowcza charakterystyka województwa wrocławskiego na dzień 5 III 1949 r., k. 2-3.

${ }^{21}$ AIPN Wr, sygn. 053/373, Raport sytuacyjny Sekcji VI Wydziału I WUBP do naczelnika Wydziału I WUBP, 28 III 1949 r., k. 19. Por. AIPN Wr, sygn. 053/624 t. 3, Kontrwywiadowcza charakterystyka województwa wrocławskiego na dzień 5 III 1949 r., k. 4. W tym dokumencie z tego samego okresu widnieje informacja o 33 powiatach w województwie wrocławskim i 10 powiatach granicznych.

22 AIPN Wr, sygn. 053/624 t. 3, Kontrwywiadowcza charakterystyka województwa wrocławskiego na dzień 5 III 1949 r, k. 1.

${ }^{23}$ Ibidem, k. 2.

${ }^{24}$ AIPN Wr, sygn. 053/373, Raport sprawozdawczy po linii referatu I-go za okres od 25 I do 25 II 1949 r., 25 II 1949 r., k. 172.

${ }^{25} \mathrm{O}$ podziałach administracyjnych zob. T. Dziki, Podziały administracyjne Polski $w$ latach 1944-1998. Z badań nad ustrojem ziem polskich w XIX $i$ XX w., „Studia Gdańskie. Wizje i rzeczywistość” 2013, t. X, s. 433-450. 
graniczny Żary został wówczas włączony do nowo utworzonego województwa zielonogórskiego, uszczuplając w ten sposób długość granicy województwa wrocławskiego o $70 \mathrm{~km}^{26}$. Co ciekawe, raport kontrwywiadowczy z $1950 \mathrm{r}$. wspomina o ubytku $70 \mathrm{~km}$, ale nie ma informacji, dlaczego długość granicy powiatu jeleniogórskiego została tym razem obliczona na $74 \mathrm{~km}^{27}$. Z kolei w 1955 r. WUdsBP lapidarnie określił długość granicy województwa wrocławskiego na $558 \mathrm{~km}, 473 \mathrm{~km}$ granicy z Czechosłowacją i $85 \mathrm{~km} \mathrm{z} \mathrm{NRD}{ }^{28}$. Trudno stwierdzić, skąd taka liczba. Po 1950 r. długość granicy województwa wrocławskiego $\mathrm{w}$ okresie stalinowskim nie została już zmieniona. Zatem jeśli założymy, że w 1955 r. wynosiła ona $558 \mathrm{~km}$, to w 19491950 razem z powiatem żarskim musiałaby mieć dodatkowe $70 \mathrm{~km}$, czyli $628 \mathrm{~km}$.

Natomiast po wojnie ziemia kłodzka obejmowała do 1954 r. dwa powiaty: kłodzki i bystrzycki ${ }^{29}$. Po przemianach administracyjnych w sierpniu $1954 \mathrm{r}$. prawa powiatu zyskała Nowa Ruda, która została wyłączona z powiatu kłodzkiego, tworząc kolejny powiat graniczny. O ile UB w Kłodzku postrzegał tereny nizinne jako stwarzajace najdogodniejsze warunki do ucieczki (szczególnie przy miejscowościach granicznych, takich jak m.in. Lewin, Słone, Radków), o tyle w powiecie bystrzyckim to górzyste i zalesione okolice Stronia Śląskiego, Międzylesia i Międzygórza stanowiły w mniemaniu bezpieki obszary zachęcające do ucieczek ${ }^{30}$. Granica ponad $160 \mathrm{~km}$ była jednak trudna do ścisłego zamknięcia, nawet przez dwa, a potem trzy urzędy powiatowe. Tylko w powiecie kłodzkim na odcinku $80 \mathrm{~km}$ z Czechosłowacja, w strefie nadgranicznej leżały 42 miejscowości, w tym 20 położonych od 50 do $1000 \mathrm{~m}$ od linii granicznej ${ }^{31}$.

${ }^{26}$ AIPN Wr, sygn. 053/624 t. 1, Kontrwywiadowcza charakterystyka województwa wrocławskiego na dzień 5 X 1950 r., listopad 1950, k. 10. Zob. Dz.U. 1950, nr 28, poz. 255, s. 315-316.

${ }^{27}$ Ibidem, Kontrwywiadowcza charakterystyka powiatu Jelenia Góra województwa wrocławskiego na dzień 24 III 1950 r., k. 97. Innych różnic dotyczących powiatów granicznych nie odnotowałem. W celu sprawdzenia i porównania charakterystyki powiatów wałbrzyskiego, ząbkowickiego i zgorzeleckiego w 1950 r. zob. AIPN Wr, sygn. 053/624 t. 2.

${ }^{28}$ AIPN Wr, sygn. 053/1586 t. 1, Ocena pracy aparatu BP województwa wrocławskiego na odcinku operacyjnego zabezpieczenia granicy, 13 X 1955 r., k. 2. W notatce Ministerstwa Spraw Zagranicznych długość granicy województwa wrocławskiego z Czechosłowacją została oszacowana na 450 km. Zob. Archiwum Akt Nowych w Warszawie (dalej: AAN), Archiwum Bolesława Bieruta, sygn. 254/IV-27, Notatka w sprawie granicy polsko-czechosłowackiej, 14 IV 1954 r., k. 130.

${ }^{29}$ Krótko proces powstania powiatowych urzędów opisuje T. Balbus, Powiatowe i miejskie Urzędy Bezpieczeństwa, w: Urzad Bezpieczeństwa na Dolnym Ślasku 1945-1956. Z badań nad organizacja $i$ działalnościa aparatu bezpieczeństwa. Studia i materiały IPN, red. R. Klementowski, K. Szwagrzyk, Wrocław 2012, s. 54, 63-65.

${ }^{30}$ Por. AIPN Wr 032/21 t. 1, Plan operacyjnego zabezpieczenie granicy PRL, 26 IV 1956 r., k. 104-105.

${ }^{31}$ Ibidem, t. 2, Plan przeprowadzenia wspólnej analizy operacyjnego zabezpieczenia odcinka granicy PRL z CSR na terenie powiatu Kłodzko, 3 IV 1954 r., k. 54. 


\section{Główne zadania UB w kontrolowaniu granic}

Analizując dokumenty UB, wyróżnić trzeba kilka głównych zadań, które miały na celu uszczelnienie granicy państwowej. Należały do nich: systematyczna analiza sytuacji granicznej, widoczna w sprawozdaniach i raportach UB; organizacja i rozbudowa sieci agentów działajacych na odcinku granicznym; wykrywanie i stała inwigilacja osób noszących się z zamiarem przekroczenia granicy; likwidacja kanałów przerzutowych; współpraca z jednostkami WOP i Milicji Obywatelskiej (MO), wymiana informacji oraz współdziałanie w przypadku wykrycia próby przekroczenia granicy.

Aby lepiej zrozumieć rolę granicy w historii ziemi kłodzkiej, warto odnieść się do wydarzeń bezpośrednio po wojnie, kiedy przynależność tego regionu do Polski była niepewna, a granica polsko-czechosłowacka wbrew temu, co głosiła komunistyczna propaganda, nie stanowiła granicy „braterskiej przyjaźni”. W latach 1945-1947 Praga rościła sobie prawa nie tylko do Ślaska Cieszyńskiego, ale także do ziemi kłodzkiej. Czesi swoje panowanie na tych terenach chcieli uzyskać jeszcze przed konferencją poczdamską, m.in. wysyłając dobrze uzbrojone jednostki wojskowe, sprzęt (samochody i pociagi pancerne) i doprowadzając do zbrojnych manifestacji ${ }^{32}$. Nastroje Czechów, którzy pozostali po stronie polskiej, wskazywały, iż głęboko wierzyli w szybkie przyłączenie tych terenów do Czechosłowacji ${ }^{33}$. Na dodatek Warszawa była skłonna oddać całość tych terenów lub ich część w zamian za ustępstwa Pragi na Zaolziu. Do żadnych zmian jednak nie doszło, bo konflikt zażegnała Moskwa, wymuszając podpisanie 10 III 1947 r. układu „o przyjaźni i wzajemnej pomocy”34. Jednak dopiero w 1958 r. w Warszawie podpisano między dwoma państwami umowę o ostatecznym wytyczeniu granicy.

Kilka miesięcy po tych wydarzeniach starosta kłodzki w raporcie o problemach granicznych odniósł się do historycznego sporu polsko-czechosłowackiego, oceniając jednocześnie rolę granicy w funkcjonowaniu powiatu: „Jeżeli uwzględni się dodatkowo moment polityczny, a mianowicie fakt, że ziemia kłodzka, uważana była przez pewne czynniki reakcji czeskiej za

${ }^{32}$ Zob. AAN, Grupy Operacyjne Komitetu Ekonomicznego Rady Ministrów (dalej: GO KERM), sygn. 246, Sprawozdanie z odprawy pełnomocników powiatowych KERM z dn. 1 VII 1945 r., k. 36; A. Herzig, M. Ruchniewicz, Dzieje Ziemi Kłodzkiej, tłum. V. Grotowicz, Hamburg-Wrocław 2006, s. 390-391.

${ }^{33}$ Archiwum Straży Granicznej w Szczecinie (dalej: ASG), Sudecka Brygada Wojsk Ochrony Pogranicza (dalej: SB WOP), sygn. 302/11, Sprawozdanie miesięczne 52 odcinka WOP za luty, 27 II 1946 r., k. 6v. 52 Komenda Odcinka znajdowała się w Dusznikach Zdroju i pod taką nazwą funkcjonowała do $1948 \mathrm{r}$.

${ }^{34}$ Szerzej o tym powojennym konflikcie zob. P. Pałys, Czechosłowackie roszczenia graniczne wobec Polski 1945-1947. Racibórz, Głubczyce, Kłodzko, Opole 2007; M.K. Kamiński, Polsko-czechostowackie stosunki polityczne 1945-1948, Warszawa 1990; T. Marczak, Granica zachodnia $w$ polskiej polityce zagranicznej w latach 1944-1950, Wrocław 1995, s. 445-534. 
obszar należny historycznie, gospodarczo i etnicznie do Czechosłowacji, to rola granicy wzrośnie jeszcze bardziej”35.

$\mathrm{W}$ celu powzięcia walki z uciekinierami oraz domniemanymi agentami zachodniego wywiadu UB prowadziło systematyczne analizy strefy i pasa granicznego. Zakładano tzw. teczki obiektowe, w których zawierano m.in. kontrwywiadowczą charakterystykę terenu. Z czego składała się taka charakterystyka? Każdy urząd musiał znać miejsca szczególnie narażone na przekroczenie granicy, najbardziej zalesione lub trudno dostępne do systematycznego patrolowania. Za takie miejsca uważano także wsie, wszelkiego rodzaju wolno stojące zabudowania, gdzie osoby próbujące przekroczyć granicę, mogły znaleźć potencjalną pomoc. Szczególną uwagę resort terroru zwracał także na transport graniczny. Stacje kolejowe i autobusowe były na bieżąco sprawdzane. Ze wzmożoną czujnością obserwowano także nowo powstające zabudowania i ruch robotników wokół budowy. Znajomość topografii terenu była bardzo cenna, rozrysowywano szlaki i miejsca, którymi najczęściej poruszały się osoby przekraczające granicę. Stąd też w teczce obiektowej często zamieszczano mapy topograficzne, liczne zeznania osób zatrzymanych, na podstawie których bacznie obserwowano wskazane przez nich miejsca przekroczenia granicy oraz oczywiście doniesienia agenturalne. W charakterystykę kontrwywiadowczą wpisywały się także m.in. informacje o zlikwidowanych kanałach przerzutowych i wykaz osób podejrzanych o przekroczenie granicy. Nie zabrakło także planów pościgu na wypadek wykrycia ucieczki i podjęcia na tym polu współpracy ze Zwiadem WOP i oddziałami $\mathrm{MO}^{36}$. Oczywiście, aby zawarte $\mathrm{w}$ teczce informacje miały stałą wartość dla resortu, musiały być one na bieżąco aktualizowane.

Wspomniane utrudnienia dla mieszkańców strefy nadgranicznej i pasa granicznego w $1951 \mathrm{r}$. stały się jeszcze większe. Rozpoczęto działania mające na celu oczyszczenie tego terenu. 3 II 1951 r. Prezydium Rządu podjęło uchwałę w sprawie zamieszkania i pobytu w pasie granicznym. Przede wszystkim rozszerzono możliwość wydania zakazu mieszkania nie tylko w strefie nadgranicznej, ale także w całym pasie granicznym. Decyzję o zakazie lub zezwoleniu na zamieszkanie w pasie granicznym (w uchwale wszystkie wytyczne dotyczace pasa granicznego obowiązywały także w strefie nadgranicznej) podejmowało Prezydium Wojewódzkiej Rady Narodowej (PWRN), po wcześniejszym zapoznaniu się z orzeczeniem wstępnym prezydium na szczeblu powiatu lub miasta. Uchwała podpisana przez premiera

${ }^{35}$ Archiwum Państwowe we Wrocławiu, Oddział w Kamieńcu Ząbkowickim (dalej: APKZ), Starostwo Powiatowe w Kłodzku, sygn. 843, Problemy graniczne powiatu kłodzkiego, 10 V 1948 r., k. 1. Kopia dokumentu znajduje się także w: AAN, Ministerstwo Ziem Odzyskanych, sygn. 1304, k. 191-197.

36 AIPN Wr, sygn. 053/3374, Ochrona granicy przed przenikaniem agentów obcego wywiadu, czerwiec 1956 r., k. 8-10. 
Józefa Cyrankiewicza wstępnie obowiązywała od 3 II do 31 XII 1951 r. ${ }^{37}$ Jednak była ona odnawiana i przedłużana z roku na rok $^{38}$. Punkt wyjśsia wszczęcia takiego postępowania stanowił wyłącznie wniosek PUBP lub brygady $\mathrm{WOP}^{39}$. Od $1955 \mathrm{r}$. takie kompetencje zyskała także $\mathrm{MO}^{40}$. We wnioskach UB argumentowało swoje stanowisko zawsze w jeden i ten sam sposób: „Przebywanie w/w w strefie nadgranicznej z uwagi na bezpieczeństwo granic R.P. jest niewskazane”. Podkreślano, że osoby te moga prowadzić stała obserwację terenu, znają miejsca słabiej zabezpieczone przez WOP, pomagaja innym w nielegalnym przekroczeniu granicy, nadzoruja kanały przerzutowe, a także udzielaja pomocy w przenikaniu do Polski agentom. Poniekąd potwierdzały to zeznania osoby przesłuchanej przez UB, zatrzymanej na próbie ucieczki z kraju. W protokole przesłuchania została odnotowana wypowiedź: „Do przekroczenia granicy nikt nam nie pomagał, ponieważ mieszkając $\mathrm{w}$ tamtych okolicach sami wiedzieliśmy którędy można przejść" 41 .

Osobom przesiedlonym do nowego miejsca zamieszkania przysługiwała pomoc ze strony terenowych rad narodowych $\mathrm{w}$ zagospodarowaniu i rozpoczęciu pracy, bowiem jak głosiła instrukcja do uchwały: „Osoba przesiedlona nie może być materialnie poszkodowana" ${ }^{2}$. Skargi i zażalenia spływajace od mieszkańców terenów nadgranicznych wykazały, że prezydia powiatowych rad narodowych (PPRN) w wielu przypadkach nie przestrzegały postanowień uchwały i dopuściły się rażących uchybień. Ograniczały się tylko do wskazania województwa lub powiatu, gdzie dana osoba miała się przenieść, bez wskazania konkretnego miejsca zamieszkania (numer domu) i pracy według posiadanych kwalifikacji. W związku z tymi uchybieniami PWRN we Wrocławiu ustaliło, że nadesłane przez rady powiatowe orzeczenia wstępne

37 APWr, PWRN, sygn. XVIII/384, Uchwała Prezydium Rządu z dnia 3 II 1951 roku o właściwości władz i postępowaniu w sprawach zamieszkiwania i pobytu w pasie granicznym, 3 II 1951 r., k. 4.

${ }^{38}$ Decyzja o zakazie zamieszkania w pasie granicznym była przedłużana stosownymi uchwałami: nr 894 z 21 XII 1951 r., nr 1213 z 27 XII 1952 r., nr 1/54 z 11 I 1954 r. i nr 581/55 z 27 VII 1955 r. Zob. APWr, PWRN, sygn. XVIII/389, Uchwała nr 581/55 Prezydium Rządu z dnia 27 VII 1955 r. w sprawie przedłużenia mocy obowiązującej uchwały nr 76a z dnia 3 II 1951 r. o właściwości władz i postępowania w sprawach zamieszkiwania i pobytu w pasie granicznym, 27 VII 1955 r., k. 98.

${ }^{39}$ APWr, PWRN, sygn. XVIII/384, Instrukcja o właściwości władz i trybie postępowania w sprawach zakazu zamieszkiwania i pobytu w pasie granicznym, 6 II 1951 r., k. 9.

40 APWr, PWRN, sygn. XVIII/389, Uchwała nr 581/55 Prezydium Rządu z dnia 27 VII 1955 r. w sprawie przedłużenia mocy obowiązującej uchwały nr 76a z dnia 3 II 1951 r. o właściwości władz i postępowania w sprawach zamieszkiwania i pobytu w pasie granicznym, 27 VII 1955 r., k. 98.

${ }^{41}$ AIPN Wr, sygn. 038/3438, Protokół z przesłuchania podejrzanego, 10 VII 1948 r., k. 30.

${ }^{42}$ APWr, PWRN, sygn. XVIII/384, Instrukcja o właściwości władz i trybie postępowania w sprawach zakazu zamieszkiwania i pobytu w pasie granicznym, 6 II 1951 r., k. 10. 
o przesiedleniu zostaną uchylone, jeśli nie będą zawierać ścisłego adresu nowego miejsca zamieszkania i pracy ${ }^{43}$.

W wielu przypadkach osoby, które otrzymały decyzję o opuszczeniu swoich gospodarstw i domów, wnosiły odwołania. Najczęściej nie przynosiły one pożądanego efektu. Zdarzały się jednak wyjątki. Tak było w przypadku pracownika funduszu wczasów pracowniczych, mieszkającego w Kudowie Zdroju, który w sierpniu 1953 r. otrzymał decyzję o opuszczeniu miejsca zamieszkania. Argumentowano to tym, że jego rodzina rok wcześniej także została przesiedlona. Po napisanym odwołaniu 3 IX 1953 r. do PWRN i odrzuceniu wniosku poszkodowany zwrócił się do Bolesława Bieruta, zaczynając swój list słowami: „Towarzyszu Prezydencie! Zwracam się do Was jako do Ojca naszego Narodu, ponieważ nikt i nigdzie nie chce mnie zrozumieć" ${ }^{44}$. Trudno powiedzieć, czy Bierut interweniował (wydaje się to raczej mało prawdopodobne), ale zwrócenie się ze skargą do samego I sekretarza spowodowało, że PWRN w 1954 r. jeszcze raz rozpatrzyło sprawę, zwracając się do WUBP o wydanie opinii. Resort nie widząc zagrożenia ze strony tej osoby, wydał opinię pozytywna. W związku z tym 22 IV 1954 r. PWRN cofnęło decyzję Prezydium w Kłodzku i zezwoliło mieszkańcowi Kudowy na pozostanie w swoim domu. Jak widać, po odrzuceniu odwołania przez administrację lokalną zdesperowanym osobom nie pozostawało już nic innego, jak błagalne w swoim wydźwięku listy słane do Bieruta lub nawet do Konstantego Rokossowskiego, pisane w języku rosyjskim ${ }^{45}$.

Przesiedlenia z obszaru granicznego wcale nie zmniejszały ryzyka nielegalnego przekraczania granicy. Okazało się, że opuszczone budynki oraz te, które po wojnie nie zostały zagospodarowane, mogły być miejscem ukrywania się tzw. przestępców granicznych. Podkreślano, że służą one do prowadzenia stałej obserwacji granicy i pozwalaja poznać dogodne miejsca na jej przekroczenie ${ }^{46}$. W związku z tym PWRN we Wrocławiu po konferencji odbytej 5 IV 1952 r. wydało dwa dni później rozporządzenie, w którym zleciło powiatowym prezydiom m.in. rozbiórkę budynków niezamieszkałych i nienadających się do odbudowy. Na każdy budynek wytypowany przez komisję miał zostać sporządzony protokół. Decyzję o rozbiórce podejmowała komisja na szczeblu powiatu, która miała składać się z przedstawiciela Wydziału Rolnictwa, Wydziału Gospodarki Komunalnej i Mieszkaniowej, Wydziału

${ }^{43}$ Ibidem, PWRN do przewodniczących prezydiów powiatowych i miejskich rad narodowych, 20 VIII 1952 r., k. 270.

${ }^{44}$ APWr, PWRN, sygn. XVIII/388, List do prezydenta Bolesława Bieruta, 18 XII 1953 r., k. 65-69. Warto zwrócić uwagę, że w tym czasie Bierut nie był już prezydentem, bowiem konstytucja z 22 VII 1952 r. znosiła ten urząd.

45 Ibidem, Гражданину генералу Маршалу Польшу Рокоссовскому, 18 III 1954 r., k. 146-150.

${ }^{46}$ APWr, PWRN, sygn. XVIII/384, Pełnomocnik graniczny rejonu wrocławskiego w Kłodzku do przewodniczącego Prezydium Wojewódzkiej Rady Narodowej we Wrocławiu, 12 III 1952 r., k. 143. 
Społeczno-Administracyjnego, architekta i funkcjonariusza WOP. Plany rozbiórki z podaniem dokładnych terminów należało przesłać do Wydziału Gospodarki Komunalnej i Mieszkaniowej PWRN. Z kolei w zamieszkanych domach miały zostać zaciemnione okna od strony granicy ${ }^{47}$. Wytypowania budynków i okien do zaciemnienia podejmowali się przedstawiciel WOP i wydelegowany członek PPRN. Nie wszyscy mieszkańcy pasa granicznego byli zadowoleni z takiego obrotu sprawy. Stąd też na licznych spotkaniach gromadzkich przewodniczący prezydiów przekonywali mieszkańców o konieczności wykonania tego rozporządzenia ${ }^{48}$. Jak wynika z dokumentu dotyczącego realizacji rozporządzenia PWRN we Wrocławiu, w wielu powiatach powstał problem zaorania całości pasa kontrolnego, tak aby bez przeszkód wykrywać próby przekroczenia granicy. Dla przykładu do czerwca 1952 r. w powiecie kłodzkim zaorano jedynie 60\% jego długości. Tereny górzyste i leśne zdecydowanie utrudniały wykonanie tego zadania ${ }^{49}$. Wszystkie tego typu wytyczne i rozporządzenia płynące z prezydium, a także ich realizacja przez niższe agendy, powinny być przekazywane do wiadomości UB, aby ten mógł na bieżaco zapoznawać się z charakterystyką terenu.

Innym problemem dla UB było kontrolowanie małego ruchu granicznego, czyli uproszczonego trybu przekraczania granicy państwowej w wyniku umowy zawartej między Polska a Czechosłowacją z 1925 r. Początkowo nad małym ruchem granicznym czuwały PRN, które wydawały przepustki. Dzieliły się one na jednorazowe, stałe i gospodarcze ${ }^{50}$. Innymi podmiotami uprawnionymi do wydawania przepustek byli starosta powiatu nadgranicznego oraz WOP. Uchwałą Prezydium Rządu z 31 V 1953 r. obowiązek ten został przekazany powiatowym organom $\mathrm{MO}^{51}$. Jak wskazują dokumenty Prezydium i MO, w większości decyzje dotyczące wydania przepustek były odmowne. W $1949 \mathrm{r}$. rekordzistami w tym zakresie były organy WOP, które odrzucały podobno

${ }^{47}$ Ibidem, Protokół z narady roboczej odbytej w dniu 5 IV 1952 r. w Prezydium Wojewódzkiej Rady Narodowej we Wrocławiu w sprawach granicznych z udziałem przedstawicieli WOP-u oraz przewodniczących prezydiów powiatowych rad narodowych powiatów granicznych, k. 147. Proces rozbiórek niezamieszkałych domów trwał lata. Także w 1956 r. zostały odnotowane przypadki rozbiórki domów leżących w pobliżu granicy. Zob. ASG, SB WOP, sygn. 297/14, Ocena sytuacji operacyjnej dowódcy 52 Batalionu WOP, lipiec 1956 r., k. 150.

48 APWr, PWRN, sygn. XVIII/384, Sprawozdanie z realizacji zarządzenia Prezydium Wojewódzkiej Rady Narodowej z dnia 7 IV 1952 r., nr 56/tjn/52, 11 VI 1952 r., k. 171.

${ }^{49}$ Ibidem, k. 172.

50 Dz.U. 1926, nr 43, poz. 263, s. 517-518.

51 APWr, PWRN, sygn. XVIII/386, Zarządzenia na podstawie uchwały Prezydium Rządu nr 410/53 z dnia 30 V 1953 r., 31 VIII 1953 r., k. 22. Por. Ł. Grabowski, M. Maruszak, op. cit., s. 311. Do innych zadań MO przy zabezpieczeniu granicy należały także: wydawanie zezwoleń na pobyt w strefie nadgranicznej, pomoc przy wydawaniu przez prezydia powiatowych lub miejskich rad narodowych zezwoleń na zamieszkanie w strefie nadgranicznej, wydawanie przepustek turystycznych, współudział w pościgach. Zob. T. Bielecki, Granice państwowe w systemie prawa państwa socjalistycznego, Warszawa 1972, s. 118-119. 
od 70 do 90\% wniosków, najczęściej bez podania przyczyny. Zostały nawet odnotowane przypadki unieważnienia przepustek wydanych przez starostów ${ }^{52}$. Tego typu działania najbardziej uderzały w osoby, które mieszkały niedaleko granicy i pracowały po stronie czechosłowackiej. Brak zgody na przepustkę oznaczał zwolnienie z pracy. Władze obu stron w latach 1948-1952 wydały szereg rygorystycznych zarządzeń, które znacząco utrudniły korzystanie z małego ruchu granicznego. Wzrost niezadowolenia ludności mieszkającej przy granicy spowodował, że stopniowo rozporządzenia były anulowane ${ }^{53}$. Ograniczano w ten sposób mały ruch graniczny i możliwość przekraczania granic przez „,jednostki niepożądane”. Na ten problem powiatowe resorty ziemi kłodzkiej, przynajmniej do 1955 r., nie zwracały szczególnej uwagi. Jak wynika z kontroli pracy PUdsBP w Kłodzku, przeprowadzonej przez WUdsBP w 1955 r., lokalny aparat nie sprawdzał osób korzystających z małego ruchu granicznego. W samej tylko Kudowie w ten sposób granicę przekraczało 100 osób dziennie ${ }^{54}$. Najwidoczniej kontrola i wytyczne z województwa pomogły, bo sytuacja zmieniła się nieco w połowie 1956 r. PUBP w Kłodzku zaczą zwracać uwagę na te rejony powiatu, gdzie blisko granicy mieszkały osoby mające krewnych w Czechosłowacji i korzystające z przepustek. Wówczas informatorom nakazano inwigilację tej grupy osób ${ }^{55}$.

Na ruch graniczny miały także wpływ wydarzenia międzynarodowe. Po tragicznym powstaniu na Węgrzech w październiku i listopadzie 1956 r., bezwzględnie zdławionym przez wojsko sowieckie, Ministerstwo Spraw Zagranicznych PRL podjęło decyzję o przywróceniu obowiązku posiadania wiz przez obywateli z Węgier, którzy zamierzali przyjechać do PRL. Decyzja weszła w życie od 10 XII 1956 r. i miała charakter tymczasowy „na okres całkowitego ustabilizowania się sytuacji na Węgrzech”. W związku z tym na granicy oprócz ważnych paszportów wymagano od Węgrów okazania wiz. To samo dotyczyło oczywiście Polaków udających się na Węgry ${ }^{56}$.

Zagadnieniami, na które aparat represji zwracał szczególną uwagę, były rozbudowa i dobre funkcjonowanie sieci agenturalnej. Już w pierwszej, tymczasowej instrukcji pracy operacyjnej z 1945 r. podkreślano: „Jeśli otrzymamy informację, że jakiś osobnik zajmuje się przestępczą działalnościa, to najszybsze i najpewniejsze dane o jego wrogiej działalności otrzymamy tylko

${ }^{52}$ Archiwum Ministerstwa Spraw Zagranicznych w Warszawie (dalej: AMSZ), z. 7, w. 42, t. 406, Wydział Czechosłowacki - Notatka Kosmala, 1 III 1949 r., k. 18.

${ }^{53}$ AMSZ, z. 7, w. 41, t. 400, Notatka informacyjna o sprawach wynikających ze stosunków polsko-czechosłowackich w ostatnim okresie, 1957 r., k. 7.

54 AIPN Wr, sygn. 053/1626 t. 4, Protokół z przeprowadzonej inspekcji w Powiatowym Urzędzie do spraw Bezpieczeństwa Publicznego w Kłodzku, 11 X 1955 r., k. 89.

${ }_{55}$ AIPN Wr, sygn. 032/21 t. 1, Plan operacyjnego zabezpieczenia granicy PRL, 26 IV 1956 r. k. 111 .

${ }^{56}$ ASG, SB WOP, sygn. 297/15, Notatka szefa Sztabu 5 Brygady WOP do dowódcy Batalionu WOP w Bystrzycy, grudzień 1956 r., k. 111. 
w tym wypadku, jeśli będziemy mieli przy nim wiernego, oddanego nam człowieka, tzw. agenta" ${ }^{57}$. Początkowo osobowe źródło informacji ${ }^{58}$ tworzyli: informator, agent i rezydent ${ }^{59}$ oraz nieformalnie kontakt operacyjny ${ }^{60}$, nieujęty w instrukcji operacyjnej do $1970 \mathrm{r}$.

UB, oprócz zakładania typowych spraw operacyjnych na konkretne osoby podejrzane o przestępstwa graniczne, prowadził także działania o charakterze profilaktycznym, polegajace na ujawnieniu i udaremnieniu za pomoca sieci agenturalnej próby ucieczek z kraju. Jeśli UB pozyskał informacje, że dana osoba zamierza zbiec za granicę, zakładano wówczas tzw. sprawę agenturalnego sprawdzenia. W teczce gromadzono wszystkie możliwe informacje na temat danej osoby, przede wszystkim donosy agentów, szczegółowe opracowane plany mające na celu potwierdzenie zamiaru ucieczki itd. ${ }^{61} \mathrm{~W}$ nurt tych działań wpisywało się także dokładne rozpracowanie osób przybyłych na dany teren $\mathrm{z}$ innych rejonów Polski, np. w celach zarobkowych przy budowach. Podkreślano, że do tego typu prac przyjmuje się ludzi, których nikt dokładnie nie sprawdza i nie melduje na czas określony na danym terenie. Osoby te miały dużą swobodę poruszania się w strefie nadgranicznej, przez co mogły dokładnie poznać teren. UB przyglądał się także osobom żyjącym ponad stan. Zakładano bowiem, że osoby takie moga mieć inne źródło finansowania, w domyśle zachodnie. W przypadku omawianego terenu dochodził tutaj także czynnik turystyczny, który wzmagał ruch w strefie nadgranicznej i powodował wzmożona czujność bezpieki i oddziałów Zwiadu $\mathrm{WOP}^{62}$. Powiatowe urzędy z zaniepokojeniem przyglądały się wzmożonemu

${ }^{57}$ Instrukcja (tymczasowa) [o] pozyskaniu, pracy i ewidencji agenturalno-informacyjnej sieci, w: Instrukcje pracy operacyjnej aparatu bezpieczeństwa 1945-1989, oprac. T. Ruzikowski, Warszawa 2004, s. 23.

58 Szerzej zob. F. Musiał, Osobowe źródta informacji pionów operacyjnych Stużby Bezpieczeństwa działajacych w granicach PRL, w: Osobowe źródła informacji-zagadnienia metodologiczno-źródtoznawcze, red. F. Musiał, Kraków 2008, s. 27-48; W. Sawicki, Osobowe źródto informacji organów bezpieczeństwa Polski Ludowej, „Aparat Represji w Polsce Ludowej 1944-1989” 2007, nr 5, s. 9-18; M. Komaniecka, Osobowe źródto informacji w technice operacyjnej, „Aparat Represji w Polsce Ludowej 1944-1989” 2007, nr 5, s. 19-27.

${ }_{59}$ Szerzej zob. Instrukcja nr 012/53 o pracy aparatu bezpieczeństwa z siecia agenturalna, w: Instrukcje pracy operacyjnej..., s. 31-46.

${ }^{60}$ Filip Musiał kontaktem operacyjnym określił osobę, która nie podpisała zobowiązania do współpracy z UB, a informacji udzielała najczęściej ustnie. Zob. F. Musiał, Zamiast wprowadzenia: archiwalia komunistycznego aparatu represji, w: Wokót teczek bezpieki. Zagadnienia metodologiczno-źródtoznawcze, red. F. Musiał, wyd. 2, Kraków 2015, s. 48, przypis 253. Z kolei Łukasz Kamiński podaje, że jest to „od 1970 r. niższa kategoria agentury, podlegająca rejestracji; w pionie wywiadu odpowiednik tajnego współpracownika”. Zob. Ł. Kamiński, Lingua securitatis, „Pamięć i Sprawiedliwość” 2003, nr 1 (3), s. 211.

${ }^{61}$ Zob. AIPN Wr, sygn. 024/5197, Postanowienie o założeniu sprawy agenturalnego sprawdzenia, 8 VI 1955 r., k. 1 i n.

${ }^{62}$ Szerzej zob. P. Sroka, Turystyka $w$ polskich Sudetach $w$ latach 1945-1956, Wrocław 2013, s. $71-106$. 
ruchowi turystycznemu, jednak - jak wynika z raportów - zrobiły niewiele, aby uszczelnić granicę, np. w okolicach Międzygórza i szczytu Śnieżnika. Z raportu kontrolnego PUBP w Bystrzycy Kłodzkiej, do którego należał ten rejon, dowiadujemy się, że powiatowy resort nie posiadał tam nawet jednego informatora. To samo dotyczyło innych miejscowości wypoczynkowych, takich jak Lądek Zdrój czy Stronie ${ }^{63}$.

Jak wskazują instrukcje pracy z agentura, werbunek do tego konkretnego zadania miał odbywać się wyłacznie wśród osób pozytywnie ustosunkowanych do „władzy ludowej”. Wykluczano werbowanie osób do współpracy na podstawie materiałów kompromitujących, czyli tzw. kompromatów ${ }^{64}$. Jak jednak można przeczytać w niektórych dokumentach bezpieki, łamano tę regułę. Wydział IX WUBP we Wrocławiu we wrześniu 1952 r. założył sprawę operacyjna o kryptonimie „, $\mathrm{E}-1$ ”. W ramach rozpracowania, wykorzystując sieć agenturalna, zbierano informacje o osobach mogących tworzyć kanał przerzutowy w województwie wrocławskim. Z charakterystyki agentury pomagającej w rozpracowaniu osób podejrzanych dowiadujemy się, że informator „Dzikowski” został zwerbowany przez MO w Bystrzycy Kłodzkiej na „zaczepnych kompromateriałach”, a informatorzy „Zakrzewski” i „Skowroński” - na podstawie kompromateriałów przez Sekcję V Wydziału IX ${ }^{65}$.

Informatorów starano się pozyskiwać ze względów lojalnościowych, ale także dlatego, że mieszkali lub pracowali blisko granicy i mogli obserwować wyznaczony odcinek graniczny. Wartościową agenturą były również osoby, które znały uciekinierów i ich rodziny lub należały do środowiska tworzącego kanały przerzutowe. Osoba aresztowana przez UB miała niewielkie pole manewru. Mogła przyznać się do winy i pójść na współpracę albo trafić do więzienia. W okresie stalinowskim bardzo częstą praktyką było aresztowanie osoby, która odmawiała współpracy z UB. „Tajne zdjęcie”, które często stosowano przy aresztowaniu, oznaczało, że rodzina miała nic nie wiedzieć o losie osoby werbowanej ${ }^{66}$. Dawało to bezpiece możliwość uzyskania bardzo istotnych informacji, nie tylko jak uciekinier przygotowywał się do przekroczenia granicy, ale także gdzie osiadł i czy planuje powrót ${ }^{67}$. W przypadku

${ }^{63}$ AIPN Wr, sygn. 053/629, Raport z przeprowadzonej kontroli PUBP w Bystrzyca po linii granicy w myśl wytycznych w piśmie naczelnika Wydziału I, 31 III 1954 r., k. 70.

${ }^{64} \mathrm{~W}$ żargonie komunistycznych służb specjalnych określano tak materiały kompromitujące, często o charakterze obyczajowym, służące do szantażu i pozyskania w ten sposób agentury. Por. Z. Uniszewski, Żargon zawodowy pracowników śledczych i operacyjnych. Problematyka kryminalistyczna, Wrocław 1999, s. 145-146. „Kompromat” to słowo zapożyczone z języka rosyjskiego i skrót od „компрометирующий материал”. W PRL używano terminu „kompromateriały”.

${ }^{65}$ AIPN Wr, sygn. 024/6933, Plan operatywnych przedsięwzięć do sprawy wstępnej kryptonim „士-1”, 11 IX 1952 r., k. 14.

66 T. Ruzikowski, Wstep, w: Instrukcje pracy operacyjnej..., s. 10-11.

${ }^{67}$ AIPN Wr, sygn. 053/394, Sprawozdanie kwartalne z pracy PUdsBP w Kłodzku za okres od dnia 1 I 1956 do 31 III 1956 r., 30 III 1956 r., k. 133. 
osób, wobec których zachodziło przypuszczenie działalności szpiegowskiej dla obcego wywiadu, bezpieka rozpoczynała aktywne rozpracowanie zmierzające do ustalenia wszystkich kontaktów, znajomych i członków rodziny uciekiniera. Warto zauważyć, że wówczas każde przekroczenie granicy od zewnątrz traktowano jako przedostanie się agenta obcego wywiadu. Zlecano obserwację tych osób i uruchomienie sieci agenturalnej w celu pozyskania możliwie jak największej ilości danych. Starano się ustalić, czy między uciekinierem a rodzina zachodziła wymiana korespondencji. Bezpieka zwracała uwagę, czy zbiegła osoba wykazywała zainteresowanie różnego rodzaju obiektami wojskowymi, przemysłowymi lub gospodarczymi. Przyglądano się także wszystkim znajomym uciekiniera z pracy. W środowisku znajomych i przyjaciół poszukiwano potencjalnych agentów, którzy mieli nawiązać kontakt z uciekinierem, podstępem skłonić go do przyznania się do działalności szpiegowskiej, jak również uzyskać informacje o jego zainteresowaniach za granica i planach powrotu. Oczywiście w momencie zdobycia informacji o zamierzonym powrocie do kraju agent powinien o tym poinformować swojego przełożonego. Wtedy wdrażano procedury zmierzajace do przechwycenia i aresztowania podejrzanego ${ }^{68}$. Z kolei kiedy agent był bezpośrednim świadkiem przestępstwa granicznego, składał bezpośredni meldunek do WOP, jako obywatelski, oczywiście nie ujawniając swojej agenturalnej działalności ${ }^{69}$.

Tego typu rozpracowanie prowadzono nie tylko wobec osób, które zbiegły za granicę lub miały takie plany, ale także względem jednostek, których zawód wymagał nawiązywania kontaktów międzynarodowych. Takim przykładem sa chociażby wykładowcy akademiccy. W dokumencie o niewiele mówiącym tytule „Wykaz osób dla instancji partyjnych”, w teczce dotyczącej akcji repatriacyjnej z 1955 r., znajdziemy informacje o rozpracowaniu m.in. wrocławskich uczonych, takich jak historyk prof. Karol Maleczyński, matematyk prof. Hugo Steinhaus, historyk prof. Henryk Wereszycki, przy którym zanotowano: „Wrogo ustosunkowany do PRL, były członek PPS, broni usilnie pozycji w historii Piłsudskiego i Dmowskiego". Jednak ważniejsze informacje znajdowały się w kolumnie po prawej stronie, gdzie wykazano znajomych lub członków rodziny uczonych, przebywających za granicą ${ }^{70}$.

Aparat terroru w celu usprawnienia działalności nie wykluczał także pozyskania agentów wśród personelu nadgranicznych stacji kolejowych i autobusowych. Szczególnie wartościowych informatorów upatrywano w kasjerach i konduktorach, ale także w obsłudze hoteli, domów noclegowych, restauracji

${ }^{68}$ Por. AIPN Wr, sygn. 054/8 t. 1, Plan agencyjnego zabezpieczenia osób nielegalnie zbiegłych za granicę oraz ich rodzin i kontaktów na terenie gm. Działoszyn, Bogatynia i Opolno Zdrój przez agenturę PUBP Zgorzelec i Sekcji VII WOP w Bogatyni, 22 XII 1953 r., k. $57-58$.

${ }^{69}$ AIPN Wr, sygn. 053/1626 t. 4, Protokół z przeprowadzonej inspekcji w Powiatowym Urzędzie do spraw Bezpieczeństwa Publicznego w Kłodzku, 11 X 1955 r., k. 88.

70 AIPN Wr, sygn. 053/667, Wykaz osób dla instancji partyjnych, [b.d.], k. 88-91. 
czy nawet salonów fryzjerskich ${ }^{71}$. Osoby, które uciekały z innych rejonów Polski i kierowały się w stronę Czechosłowacji lub NRD przez województwo wrocławskie, mogły skorzystać z takich punktów. MBP prowadziło wtedy wzmożoną współpracę z terenowymi urzędami, wymieniając się potrzebnymi informacjami. Ciekawym przykładem jest telefonogram naczelnika Wydziału I Departamentu I MBP do naczelnika Wydziału I WUBP we Wrocławiu z 25 XI $1953 \mathrm{r}^{72}$ Zwracał się on z prośba „o natychmiastowe sprawdzenie w punktach zatrzymań dla osób przybyłych/ hotele, domy noclegowy, itd. czy przypadkiem nie przybyli na wasz teren dr Buchalik Maksymilian [...] Koleczko Edelbranda [...] wymienieni wyjechali z $\mathrm{m}$ [iejsca] zamieszkania z zamiarem nielegalnego przekroczenia granicy PRL"73. Tego typu zawiadomienie uruchamiało szereg działań. Jeszcze tego samego dnia naczelnik Wydziału I WUBP zwrócił się do szefa Wydziału VII, 8 Brygady WOP w Lubaniu i szefa Wydziału VII, 5 Brygady WOP w Kłodzku o wzmocnienie czujności na granicy. MO we Wrocławiu otrzymała nakaz sprawdzenia hoteli i miejsc noclegowych na terenie tego miasta. To samo polecenie dostały PUBP w Zgorzelcu, Lubaniu i Kłodzku. Dwa dni później z Warszawy przysłano zdjęcia uciekinierów w celu usprawnienia dalszych poszukiwań. Natychmiast także uaktywniono agenturę poszczególnych jednostek terenowych aparatu represji, która miała zasięgnąć wiadomości w tej sprawie. Jeśli nie można było pozyskać zdjęć osób poszukiwanych, sporządzano dokładny rysopis. Taki dokument z poleceniem aresztowania danej osoby i odstawienia jej do WUBP rozsyłano do wszystkich urzędów powiatowych w województwie ${ }^{74}$.

Zestawienia dotyczące ogólnego stanu agentury, będącej w dyspozycji poszczególnych urzędów powiatowych, są niepełne. Warto jednak przytoczyć kilka wybranych statystyk. Najpełniejsze dane prezentują miesięczne raporty PUBP w Bystrzycy Kłodzkiej w roku 1953. Liczba informatorów wahała się tutaj od $124 \mathrm{w}$ styczniu do $134 \mathrm{w}$ grudniu $1953 \mathrm{r}$. Rozrost agentury widzimy także w przypadku rezydentów, których na początku okresu sprawozdawczego było 3 , a pod koniec roku - 6. Jednak wymierne informacje o działalności agentury daje nam notka o znaczaccym wzroście sieci agenturalnej, której na

${ }^{71}$ AIPN Wr, sygn. 053/3374, Ochrona granicy przed przenikaniem agentów obcego wywiadu, czerwiec 1956 r., k. 12, 16.

${ }^{72}$ Wydział I WUBP był odpowiednikiem Wydziału I Departamentu I MBP. Ogólnie Departament I zajmował się kontrwywiadem, a poszczególne wydziały - rozpracowaniem agentów obcych wywiadów. Szerzej o zmianach struktury poszczególnych departamentów i wydziałów MBP zob. Z. Nawrocki, Struktura aparatu bezpieczeństwa, w: Aparat Bezpieczeństwa w Polsce. Kadra kierownicza, t. I: 1944-1956, red. K. Szwagrzyk, Warszawa 2005, s. 25-48.

${ }^{73}$ AIPN Wr, sygn. 054/8 t. 1, Telefonogram nr 1341 naczelnika Wydziału I Departamentu I MBP do naczelnika Wydziału I WUBP we Wrocławiu, 25 XI 1953 r., k. 27.

${ }^{74}$ Ibidem, szef Wydziału I WUBP we Wrocławiu do szefa PUBP w..., 11 I 1954 r., k. 51. Treść takiego dokumentu dla wszystkich PUBP była taka sama, stąd też kopiowano go zgodnie $\mathrm{z}$ liczbą PUBP w danym województwie i pozostawiano tylko miejsce na wpisanie miejscowości urzędu. 
początku roku było 75 , a w grudniu aż $93^{75}$. Z kolei ze szczątkowych danych wnioskujemy, że przeciętny stan agentury w powiecie kłodzkim w $1951 \mathrm{r}$. kształtował się na poziomie 190 informatorów, 7 rezydentów i 5 agentów ${ }^{76}$. Natomiast w schyłkowym okresie stalinowskim w powiecie noworudzkim było ok. 75 informatorów i 3 rezydentów ${ }^{77}$.

Ilu agentów pracowało na odcinku granicznym? Pod koniec $1953 \mathrm{r}$. w powiecie kłodzkim było 67 agentów/ informatorów i 2 rezydentów. W powiecie bystrzyckim podobnie: 64 i 2 . Mogłoby się wydawać, że to znaczna pomoc. Dla przykładu PUBP w Zgorzelcu na odcinku aż $130 \mathrm{~km}$ miał do dyspozycji tylko 90 jednostek agentury ${ }^{78}$. Oceny jakości pracy nie pozostawiaja jednak żadnych watpliwości. Osoby te były na niskim poziomie intelektualnym i nie spełniały zadań, jakie przed nimi stawiano. Zwracano także uwagę na niska liczbę lokali kontaktowych ${ }^{79}$, gdzie mogły odbywać się spotkania i szkolenia agentury. Innymi powtarzającymi się problemami były zdekonspirowanie wielu informatorów oraz brak chęci ze strony PUBP do powiększenia stanu rezydentury, która miała współpracować z agentura ${ }^{80}$. Kontrola WUBP wykazała, że „werbowano dla ilości bez najmniejszego wnikania w potrzeby danego odcinka granicznego i osiedlonego tam wrogiego elementu"81. Doprowadziło to do dużych „czystek” i pozbywania się jednostek „bezwartościowych” dla resortu. Według danych zebranych przez WUdsBP, w październiku 1955 r. w 7 powiatach granicznych województwa wrocławskiego nad zabezpieczeniem granic pracowało ok. 132 agentów. W powiecie kłodzkim było ich 17, w powiecie bystrzyckim - tylko 5. Nie udało się ustalić takich danych dla Nowej Rudy ${ }^{82}$. Widać więc, że redukcja agenturalnego zaplecza była ogromna.

75 Zob. sprawozdania miesięczne z tego okresu: AIPN Wr, sygn. 053/273, Raport Powiatowego Urzędu Bezpieczeństwa Publicznego w Bystrzycy Kłodzkiej za okres od 1 do 31 I 1953 r., 3 II 1953 r., k. 110 i dalej do k. 185.

${ }^{76}$ AIPN Wr, sygn. 053/305, Sprawozdanie za okres od 4 XII 1950 do 4 I 1951 r., 4 I 1951 r., k. 12.

77 AIPN Wr, sygn. 053/392, Sprawozdanie z pracy Powiatowego Urzędu Bezpieczeństwa Publicznego w Nowej Rudzie za I kwartał 1956 r., 31 III 1956 r., k. 58 i n.

${ }^{78}$ AIPN Wr, sygn. 053/629, Raport z przeprowadzonej analizy i kontroli pracy operacyjnej w Wydziale VII 5 Brygady WOP oraz PUBP powiatów granicznych, styczeń 1954 r., k. 3, 9.

${ }^{79}$ Były to pomieszczenia najczęściej prywatne, pozyskane przez UB do odbywania spotkań z agenturac. W 1955 r. w celu rozróżnienia charakteru lokali wprowadzono podział na lokale kontaktowe, czyli mieszkania prywatne użyczone UB oraz lokale (mieszkania) konspiracyjne będące własnością resortu. Zob. F. Musiał, Osobowe źródta informacji..., s. 33-34.

${ }^{80}$ AIPN Wr, sygn. 053/629, Tezy do referatu na odprawę po zagadnieniu zabezpieczenia granicy dla oficerów Wydziału VII, Brygady 8 WOP i pracowników PUBP granicznych, 8 II 1954 r., k. 27.

${ }^{81}$ Ibidem, Raport z przeprowadzonej analizy i kontroli pracy operacyjnej w myśl pisma okólnego dyrektora Gabinetu Ministra MBP nr 012/53 z dn. 30 XI 1953 r. w Wydziale VII, Brygady 5 i Wydziale VII WOP oraz PUBP powiatów granicznych, styczeń 1954 r., k. 3-4.

82 AIPN Wr, sygn. 053/1586 t. 1, Ocena pracy aparatu BP województwa wrocławskiego na odcinku operacyjnego zabezpieczenia granicy, 13 X 1955 r., k. 6. 
Jak wskazuje dalsza treść raportu, pozostałych agentów określano jako bardzo wartościowych i przydatnych, bowiem połowa z nich posiadała wykształcenie średnie lub wyższe. Niemniej jednak zaznaczano także, że liczba takich osób pracujących nad zabezpieczeniem granic była nadal niewystarczająca. Kilka miesięcy później, w maju 1956 r. stan ten nieznacznie powiększono do 21 agentów w Kłodzku i 13 w Bystrzycy ${ }^{83}$.

\section{Współpraca z WOP}

Temat realnej współpracy UB ze Zwiadem WOP w celu zabezpieczenia granicy jest trudny do jednoznacznej oceny, a na potrzeby artykułu został jedynie zasygnalizowany. Wynika to nie tylko ze skapych, czasem dosłownie jednozdaniowych informacji na ten temat, ale także z lekceważącego podejścia urzędów powiatowych do tego aspektu. Oczywiście zasady współpracy określało specjalne rozporządzenie KdsBP z 12 VII 1955 r. W teorii miało wyglądać tak, że: „Organa bezpieczeństwa publicznego współdziałaja z WOP, a w szczególności z organami Zwiadu WOP [...]. Udzielają sobie wzajemnej pomocy, wykorzystując wszelkie możliwości operacyjne w walce z przestępczością. Wymieniaja informacje, przekazuja w miare potrzeb materiały operacyjne, przekazują zadania dla agentury itp. [...] Celem skutecznej i skoordynowanej współpracy i pomocy - jednostki te utrzymują ze sobą codzienny roboczy kontakt" ${ }^{84}$. W praktyce jednak współpraca wyglądała różnie. Z poszczególnych sprawozdań PUBP w Kłodzku, Bystrzycy czy Nowej Rudzie otrzymujemy tylko szczątkowe, lapidarne określenia w stylu: „współpraca układa się pomyślnie” lub „na dobrym poziomie" 85 . Pomiędzy urzędami powiatowymi a pozostałymi jednostkami organów państwa, które działały na rzecz ochrony granic, w założeniu powinna istnieć ścisła współpraca. Przeglądając sprawozdania i raporty PUBP na ziemi kłodzkiej, dojdziemy do wniosku, że w tym aspekcie przez cały okres stalinowski nie występowały żadne poważne problemy. Kiedy jednak przyjrzymy się inspekcji i raportom kontrolnym WUBP z pracy podległych mu jednostek powiatowych, zauważymy, że współpraca ta w zasadzie nigdy

${ }^{83}$ AIPN Wr, sygn. 053/630, Sprawozdanie dotyczące zagadnienia ochrony granicy, maj 1956 r., k. 32.

${ }^{84}$ AIPN Wr, sygn. 053/3374, Ochrona granicy przed przenikaniem agentów obcego wywiadu, czerwiec 1956 r., k. 27-28.

${ }^{85}$ AIPN Wr, sygn. 053/392, Sprawozdanie z pracy Powiatowego Urzędu do spraw Bezpieczeństwa Publicznego w Nowej Rudzie za pierwszy kwartał, 31 III 1956 r., k. 58-59; AIPN Wr, sygn. 053/394, Sprawozdanie kwartalne z pracy PUdsBP w Kłodzku za okres od dnia 1 I 1956 do 31 III 1956 r., 30 III 1956 r., k. 136; AIPN Wr, sygn. 053/194, Sprawozdanie kwartalne z pracy PUdsBP w Kłodzku za okres od dnia 1 X 1955 do 31 XII 1955 r., 31 XII 1956 r., k. 167; AIPN Wr, sygn. 053/196, Sprawozdanie z pracy Powiatowego Urzędu do spraw Bezpieczeństwa Publicznego w Nowej Rudzie za okres od dnia 1 X 1955 r. do 1 I 1956 r., 28 XII 1955 r., k. 79. 
nie była ścisła. Wpływało na to kilka czynników. Jednym z nich była nadrzędna rola UB w hierarchii. WOP podlegały MBP do 1954 r., w związku z tym szefowie powiatowych urzędów wychodzili z założenia, że to Zwiad WOP ma przedstawiać raporty z sytuacji na granicy. W czasie wspólnych narad często przerzucano się odpowiedzialnością za taki stan rzeczy. UB miał najczęściej pretensje do kierownictwa WOP, że na czas nie informowało o przekroczeniu granicy, niekiedy w ogóle zatajając takie przypadki ${ }^{86}$, z kolei WOP zarzucały aparatowi bierność we włączaniu się w akcje poszukiwawcze i brak chęci tropienia zbiegów ${ }^{87}$. Na ten problem zwracano szczególnie uwagę po likwidacji MBP w 1954 r. i reorganizacji struktur resortu terroru w Polsce. Ocenę współpracy UB z WOP jasno podsumował szef PUBP w Kłodzku, który stwierdził, że „Po reorganizacji organów bezpieczeństwa, nasz kolektyw cały zaniedbał swą pracę nad zabezpieczeniem granicy państwowej, niesłusznie uważając, że całość odpowiedzialności za to zagadnienie przejął WOP"88. $\mathrm{Na}$ takie, a nie inne stosunki między aparatem represji a WOP mogły mieć wpływ inne czynniki, np. brak zaufania do żołnierzy WOP i podkreślane często przez UB podejrzane relacje $\mathrm{z}$ osobami rozpracowywanymi ${ }^{89}$. Temat ten jednak wymaga zdecydowane bardziej pogłębionej kwerendy i analizy.

\section{Wyroki sądowe}

Artykuł 22 Rozporządzenia Prezydenta Rzeczypospolitej z dnia 23 XII 1927 r. o granicach Państwa dokładnie wskazywał przestępstwa graniczne, które podlegały karze. Czytamy w nim:

Kto świadomie przekracza granicę Państwa bez właściwych dokumentów, albo $\mathrm{w}$ miejscu na to nieprzeznaczonem, albo mimo zamknięcia ruchu granicznego; podrabia lub przerabia (fałszuje) przewidziane na mocy rozporządzenia niniejszego lub na mocy rozporządzeń na niem opartych dokumenty, pieczęcie lub pieczątki

${ }^{86}$ Por. AIPN Wr, sygn. 032/21 t. 5, Notatka służbowa, 20 III 1956 r., k. 2.

${ }^{87}$ Ibidem t. 6, Protokół z narady po zagadnieniu granicy na naszym terenie, 21 III 1956 r., k. 2.

${ }^{88}$ Ibidem, Treść wystapienia szefa PUBP w Kłodzku podczas odprawy, 17 III 1956 r., k. 7. Por. AIPN Wr, sygn. 053/1586 t. 1, Ocena pracy aparatu BP województwa wrocławskiego na odcinku operacyjnego zabezpieczenia granicy, 13 X 1955 r., k. 13; AIPN Wr, sygn. 053/1626 t. 4, Protokół z przeprowadzonej inspekcji w Powiatowym Urzędzie do spraw Bezpieczeństwa Publicznego w Kłodzku, 11 X 1955 r., k. 86.

${ }^{89}$ Zob. AIPN Wr, sygn. 053/394, Sprawozdanie kwartalne z pracy PUdsBP w Kłodzku za okres od dnia 1 I 1956 do 31 III 1956 r., 30 III 1956 r., k. 129; AIPN Wr, sygn. 053/196, Sprawozdanie z pracy Powiatowego Urzędu do spraw Bezpieczeństwa Publicznego w Nowej Rudzie za okres od dnia 1 IV do 1 VII 1955 r., 30 VI 1955 r., k. 45. Głośnym echem odbiła się także sprawa por. Jana Kajdy, dowódcy strażnicy 244 WOP we wsi Konary (powiat Kłodzko), który po dokonaniu morderstwa miał zdezerterować z jednostki i założyć nielegalna organizację. Zob. AIPN Wr, sygn. 038/75. Postać Kajdy pojawia się w wielu raportach WOP, zob. m.in. ASG, SB WOP, sygn. 274/30, k. 175-177; ASG, SB WOP, sygn. 302/11, k. 40. 
urzędowe; świadomie z takich podrobionych lub przerobionych dokumentów pieczęci lub pieczątek urzędowych korzysta lub dostarcza ich innym osobom; legitymuje się dokumentem autentycznym, wskazanym w punkcie 2-gim, lecz należącym do innej osoby, lub swój, albo należący do trzeciej osoby autentyczny dokument oddaje innym osobom do legitymowania się; świadomie składa przed władzą fałszywe zeznania lub dowody, albo zamilcza ważne okoliczności dotyczące warunków, od których jest uzależnione wydanie wskazanych wyżej dokumentów lub pieczęci urzędowej na takim dokumencie, albo świadomie korzysta z dokumentu lub pieczęci w powyższy sposób uzyskanych; dopuszcza się jednego z przestępstw, wyszczególnionych w art. 19, po dwukrotnem ukaraniu za takie samo przestępstwo, albo dopuszcza się go w szerszym rozmiarze lub zawodowo, - ulega karze więzienia do 1 roku i grzywnie od $300 \mathrm{zł}$. do 10.000 zł. lub jednej z tych kar, o ile dany czyn według powszechnych ustaw karnych nie ulega karze surowszej ${ }^{90}$.

Do 1948 r. sądy w Polsce stosowały się do tego rozporządzenia. Widać to w przeanalizowanych wyrokach Sądu Grodzkiego w Kłodzku w latach 1945-1948. Na 63 przeanalizowane sprawy, w 13 przypadkach wydano wyrok uniewinniajaccy, wyrok z warunkowym zawieszeniem kary albo grzywnę. W pozostałych sąd orzekał karę pozbawienia wolności. W 8 sprawach oskarżony został skazany na 2 tygodnie aresztu, 34 razy na 4 tygodnie/ miesiąc pozbawienia wolności, 3 razy na 6 tygodni więzienia. Od 2 do 3 miesięcy więzienia orzekano w 5 sprawach $^{91}$.

Głębokie zmiany systemowe zachodzące w Polsce na wzór sowiecki dotknęły także wymiar karny. Zgromadzenie Ogólne Sądu Najwyższego 25 XI 1948 r. ustaliło, że orzecznictwo przedwojennego Sądu Najwyższego, niezgodne z obecnym systemem komunistycznym, miało wyłącznie znaczenie historyczne ${ }^{92}$. Największe zmiany w sądownictwie i prokuraturze wdrożono w latach 1949-1950, jednak kwestia granic państwa zajęto się wcześniej. Został zatwierdzony Dekret z dnia 15 IX 1948 r. o zmianie Rozporządzenia Prezydenta Rzeczypospolitej z dnia 23 XII 1927 r. o granicach państwa. Dokument ten przewidywał zaostrzenie kar za przestępstwa graniczne: „Kto przekracza granice Państwa bez właściwych dokumentów albo w miejscu na to nie przeznaczonym albo mimo zamknięcia ruchu granicznego, podlega karze więzienia na czas od 1 roku do lat 3 . W przypadkach mniejszej wagi sąd może zastosować nadzwyczajne złagodzenie kary" ${ }^{93}$. Sądy komunistyczne nie orzekały wyłącznie najwyższego wymiaru kary. Z przeanalizowanych kilkunastu spraw Sądu Okręgowego we Wrocławiu w 1950 r. wynika, że najwyższy

90 Dz.U. 1927, nr 117, poz. 996, s. 1663.

${ }^{91}$ Obliczenia autora na podstawie akt sądowych Wydziału Karnego Sądu Grodzkiego w Kłodzku. Zob. APKZ, Sąd Grodzki w Kłodzku, sygn.: 5/1-3, 3/39-41, 3/44, 3/50, 2/161-162, 2/196, 2/200-202, 2/211, 2/256, 2/321-322, 2/332, 2/336, 2/339-340, 2/351-355, 2/360-361, 2/366-372, 2/385, 2/393-395, 2/398, 2/404-410, 2/413, 2/424-425, 2/428-431, 2/449-451, $2 / 470-472,2 / 476$.

92 A. Lityński, O prawie i sqdach poczatków Polski Ludowej, Białystok 1999, s. 150.

${ }^{93}$ Dz.U. 1948, nr 47, poz. 348, s. 956. 
wymiar kary za nielegalne przekroczenie granicy wyniósł 1,5 roku więzienia, znalazło się także kilka uniewinnień, kar finansowych lub w zawieszeniu ${ }^{94}$. Dane te w żadnym stopniu nie są reprezentatywne, jednak pokazuja, że nie zapadały wyłącznie wyroki trzech lat pozbawienia wolności.

4 VIII 1948 r. Departament Więziennictwa MBP wydał instrukcję zalecająca zorganizowanie sześć więzień filtracyjnych, gdzie miały być kierowane osoby nielegalnie przekraczające granicę. Niemal wszystkie wskazane zakłady znajdowały się na Ziemiach Północnych i Zachodnich, a były to: więzienie w Złotowie i Koszalinie (województwo szczecińskie), Zielonej Górze (województwo poznańskie), Jaworze i Kłodzku (województwo wrocławskie) oraz Sosnowcu (województwo katowickie) ${ }^{95}$. Niewielkie więzienie w Kłodzku wytypowano jako jedno z sześciu więzień filtracyjnych w Polsce, do których mieli być kierowani ludzie nielegalnie przekraczający granicę. $\mathrm{W}$ związku z tym wydzielono w nim specjalny oddział dla osób zatrzymanych przez WOP. Wybór Kłodzka ze względu na swoje nadgraniczne położenie oraz bardzo długa granicę z Czechosłowacją nie był przypadkowy ${ }^{96}$.

Nieco inaczej przedstawiała się kwestia wyroków Komisji Specjalnej do Walki z Nadużyciami i Szkodnictwem Gospodarczym. Decyzja o powstaniu tego ciała zapadła 2 IX 1945 r. na posiedzeniu Biura Politycznego KC PPR, natomiast formalnie Komisja została powołana dekretem z 16 XI 1945 r. ${ }^{97}$, który dawał jej niezwykle szerokie uprawnienia. Komisja nie tylko nie musiała kierować sprawy na drogę sądowa, ale mogła od razu oskarżonego skazać na dwa lata przymusowej pracy (art. 10). Komisja miała prawo także żądać przekazania jej spraw prowadzonych przez „organa prokuratorskie lub władze sądowo-śledcze albo bezpieczeństwa publicznego”, mieszczących się w zakresie jej kompetencji (art. 12) ${ }^{98}$. Dekret z 14 V 1946 r. znowelizował ustalenia dotyczące kompetencji komisji i wprowadził określenie „obóz pracy”. Wcześniej bowiem Komisja mogła skierować oskarżonego „tylko” do pracy przymusowej, a dodatkowo orzec konfiskatę mienia osoby oskarżonej ${ }^{99}$. Jak zauważa Adam Lityński, zwłaszcza art. 10 dekretu był nadużywany, szczególnie wespół z resortem terroru. Jeśli śledztwo i zastosowane przez UB

${ }^{94}$ Zob. AIPN Wr, sygn. 038/1119, Sentencja wyroku w imieniu Rzeczypospolitej Polskiej z dnia 11 III 1950 r., k. 22; AIPN Wr, sygn. 054/1004, Sentencja wyroku w imieniu Rzeczypospolitej Polskiej z dnia 18 XI 1950 r., k. 12. Dalej zob. k. 18-20, 25, 28, 29, 34, 39, 45, 51, 380.

${ }_{95}$ AIPN, Biuro Udostępniania i Archiwizacji Dokumentów w Warszawie (dalej: BU), sygn. 01258/4, Instrukcja dla grup operacyjnych w więzieniach dla nielegalnie przekraczających granicę RP, 1948 r., k. 28.

${ }_{96}$ O działalności więzienia karno-śledczego w Kłodzku w latach 1945-1956 przygotowałem osobny artykuł, który został złożony do redakcji rocznika „Polska 1944/45-1989. Studia i materiały".

${ }_{97}$ Dz.U. 1945 , nr 53, poz. 302, s. 476-477.

98 Ibidem.

${ }^{99}$ Komisja Specjalna do Walki z Nadużyciami i Szkodnictwem Gospodarczym 1945-1954. Wybór dokumentów, wstęp i oprac. D. Jarosz, T. Wolsza, Warszawa 1995, s. 5. 
metody nie przekonały oskarżonego do uznania swojej winy, często sprawę kierowano do Komisji, która bez postępowania i bez przyznania obrońcy kierowała taką osobę do obozu pracy przymusowej na okres do dwóch lat. Zdarzały się przypadki, że wyrok zapadał bez uznania w poczet kary okresu tymczasowego aresztu, który mógł trwać dwa miesiące ${ }^{100}$, a nawet dwa lata ${ }^{101}$. Ta praktyka odbiegała od stosowanej przez sady. Z analizy zachowanych 63 spraw dotyczących przestępstw granicznych, rozpatrywanych przez Komisję Specjalna we Wrocławiu, wnioskujemy, że w bardzo niewielu przypadkach dochodziło do uniewinnienia, a równie często jak przemytem przez granicę, Komisja zajmowała się zwykłym jej przekroczeniem ${ }^{102}$. Tylko w 1949 r. delegatura we Wrocławiu za nielegalne przekroczenie granicy i przemyt skazała na obóz pracy 456 osób ${ }^{103}$.

\section{Zakończenie}

Biorac pod uwagę obfitość materiału źródłowego, przedstawiony w niniejszym tekście problem z powodzeniem mógłby doczekać się co najmniej solidnego rozdziału w pracy dotyczącej głównych kierunków działań PUBP. Odpowiadając na pytanie zawarte we wstępie, skłaniałbym się do stwierdzenia, że realnie dla PUBP na ziemi kłodzkiej kwestia ochrony granic nie stanowiła priorytetowego zadania, choć na pewno nie była ona marginalizowana. Zakładano, że od zatrzymywania i ściagania przestępców granicznych sa jednostki WOP podległe resortowi represji. „Wchłonięcie” WOP przez MBP spowodowało, że terenowe struktury aparatu przejęły szablon postępowania na granicy, charakterystyczny szczególnie dla Zwiadu WOP, niemniej jednak w tym „duecie” to UB pełnił rolę nadrzędną jako władzy ustawodawczej i wykonawczej, a WOP jedynie wykonawczej ${ }^{104}$. Współpraca między tymi dwoma organami nie wyglądała najlepiej. Wiele istniało w niej niedomówień

100 APWr, Komisja Specjalna do Walki z Nadużyciami i Szkodnictwem Gospodarczym Delegatura we Wrocławiu (dalej: KS), sygn. 372, List Zdzisława Zakrzewskiego do Prokuratora Komisji Specjalnej we Wrocławiu, 30 XI 1948 r., k. 19.

101 A. Lityński, op. cit., s. 200-201.

102 Zob. APWr, KS, sygn. 343-404, 507, 518.

${ }^{103}$ Opracowanie „Działalności Komisji Specjalnej do Walki z Nadużyciami i Szkodnictwem Gospodarczym w liczbach za lata 1946-1949”, w: Komisja Specjalna do Walki z Nadużyciami..., s. 108.

104 To właśnie Zwiad WOP był czynnikiem decydującym o represyjnym charakterze tej formacji wojskowej. W swoim działaniu Zwiad WOP niczym nie różnił się od UB/SB. Posiadał w swoich szeregach wyszkolonych funkcjonariuszy, a na usługach setki informatorów, prowadził inwigilacje i rozpracowanie „wrogich elementów”, zwalczał podziemie niepodległościowe, przeprowadzał czystki itp. Szerzej zob. J. Wygoda, Zwiad Wojsk Ochrony Pogranicza jako organ bezpieczeństwa państwa w rozumieniu ustawy lustracyjnej, „Aparat Represji w Polsce Ludowej 1944-1989” 2011, nr 8-9, s. 97-116. 
i wzajemnych oskarżeń. Za poparciem tezy, że granica państwowa w wielu miejscach była „dziurawa”, przemawia kilka faktów. Warto zaczać od statystyki, która naświetli skalę problemu nielegalnego przekraczania granic. Według rocznego raportu statystycznego, przeprowadzonego przez WUBP we Wrocławiu, w 1953 r. za usiłowanie nielegalnego przekroczenia granicy lub pomoc w występku zatrzymano łącznie 325 osób, zaś rok później - $259^{105}$. Według niepełnych informacji w latach 1946-1952 z powiatu kłodzkiego zbiegło ok. 30 osób, ale były to wyłącznie osoby, które wcześniej zamieszkiwały ten teren. Tyle przypadków udało się UB potwierdzicic ${ }^{106}$. Liczba osób, którym faktycznie udało się przekroczyć granicę (tym zamieszkałym w powiecie i tym, które przybyły z innego regionu), nie jest możliwa do określenia, choćby z powodu tego, że WOP nie informował o każdym przypadku UB, tak jak powinien. UB z kolei nie przekazywał informacji o rozpracowywanych osobach i niepowodzeniach dotyczących ich ucieczek. Warto tutaj przytoczyć kilka przykładów tych ucieczek i opieszałości aparatu represji w uchwyceniu lub określeniu personaliów danej osoby. Przykładowo Bolesław Benedykt do 1949 r. sześciokrotnie nielegalnie przekraczał granice i ani razu nie został schwytany, a w 1949 r. nie wrócił już do Polski ${ }^{107}$. W tym samym sprawozdaniu otrzymujemy niejako przyznanie się do „grzechów” aparatu represji w Kłodzku. Jednoznacznie zostaje stwierdzone, że na 12 spraw ewidencyjno-obserwacyjnych nie ustalono nawet podstawowych danych dotyczacych uciekinierów ani miejsca, w którym nielegalnie przekroczyli granicę ${ }^{108}$. Z kolei przykładem bezradności PUBP w Bystrzycy Kłodzkiej jest sprawa „inżyniera Pstrowskiego", który symulujac chorobę psychiczna, został osadzony w szpitalu psychiatrycznym w Stroniu Ślaskim, z którego niedługo potem zbiegł, przekraczając pobliska granicę. PUBP o tym fakcie dowiedziało się kilka miesięcy później, a w następnych raportach wracajacc do tej spektakularnej sprawy, nadal nie potrafiło ustalić dokładnych danych osoby zbiegłej oraz okoliczności, w jakich doszło do przekroczenia granicy ${ }^{109}$. Takie przykłady można by mnożyć. Innym ciekawym źródłem, pokazującym problemy z zabezpieczeniem granicy, sa akta spraw sądowych. Na poszczególną teczkę składa się kilka dokumentów, takich jak: akt oskarżenia, spisane przesłuchanie oskarżonego, protokół dochodzenia, najczęściej także postanowienie o tymczasowym

\footnotetext{
${ }^{105}$ AIPN Wr, sygn. 053/629, Roczny raport statystyczny, 25 I 1955 r., k. 286.

${ }^{106}$ AIPN Wr, sygn. 032/21 t. 2, Plan agencyjnego zabezpieczenia osób nielegalnie zbiegłych za granice oraz ich rodzin i kontaktów na terenie pow. Kłodzko, 30 I 1954 r., k. 62.

107 AIPN Wr, sygn. 053/394, Sprawozdanie kwartalne z pracy PUdsBP w Kłodzku za okres od dnia 1 I 1956 do 31 III 1956 r., 30 III 1956 r., k. 127.

108 Ibidem, k. 135. Por. AIPN Wr, sygn. 053/392, Plan agenturalno-operacyjnych przedsięwzięć Powiatowego Urzędu do spraw Bezpieczeństwa Publicznego w Nowej Rudzie za okres IV-go kwartału 1956 r., 29 IX 1956 r., k. 97.

109 AIPN Wr, sygn. 053/273, Raport Powiatowego Urzędu Bezpieczeństwa Publicznego w Bystrzycy Kłodzkiej za okres od dnia 1 do 30 VI 1953 r., 3 VII 1953 r., k. 139.
} 
aresztowaniu, protokół z rozprawy oraz oczywiście sentencja wyroku. Wczytując się $\mathrm{w}$ przesłuchanie oskarżonych osób, zauważamy ciekawą prawidłowość. Otóż zdecydowana większość z nich przekroczyła granice po stronie polskiej bez większego problemu, a dopiero po stronie czechosłowackiej zostali oni schwytani przez tamtejsze partole graniczne i przekazani UB. Skala tego zjawiska każe się zastanowić nad rzeczywistą skutecznością resortu represji i podległych mu jednostek $\mathrm{w}$ kontrolowaniu granicy państwowej $\mathrm{w}$ okresie stalinowskim.

\section{Streszczenie}

Autor na przykładzie ziemi kłodzkiej podją się przedstawienia jednego z kluczowych aspektów działalności aparatu bezpieczeństwa w okresie stalinowskim - kontroli granic. Od 1949 r., kiedy w struktury Ministerstwa Bezpieczeństwa Publicznego zostały włączone Wojska Ochrony Pogranicza oraz zaostrzyła się ogólna polityka migracyjna, resort kładł duży nacisk na zabezpieczenie granicy państwowej. Dotyczyło to wszystkich województw, jak i powiatów granicznych. Autor przeanalizował i wyróżnił kilka głównych zadań Urzędu Bezpieczeństwa na polu zamknięcia i zabezpieczenia granicy. Skupił się na przedstawieniu kontrwywiadowczej charakterystyki terenu i systematycznej analizy sytuacji granicznej w latach 1949-1956. Opisał organizację i rozbudowę sieci agentów działających na odcinku granicznym, wykrywanie i stałą inwigilację osób noszących się z zamiarem przekroczenia granicy, likwidację kanałów przerzutowych podjętą rzez UB, a także współpracę z jednostkami WOP i MO. Autor w krótkim zarysie przedstawił także konsekwencje, jakie groziły osobom nielegalnie przekraczajacym granicę. Między innymi na podstawie wyroków Sądu Grodzkiego w Kłodzku i Sądu Okręgowego we Wrocławiu zreferował najczęściej zapadające wyroki. Analizując także materiały Komisji Specjalnej do Walki z Nadużyciami i Szkodnictwem Gospodarczym, odpowiedział na pytanie, czy organ ten był w omawianej sferze bardziej represyjny, skazując na wyższe wyroki. W zakończeniu autor udzielił odpowiedzi na zasadnicze pytanie, czy granica państwowa Polski w okresie stalinowskim rzeczywiście była tak szczelna i niemożliwa do sforsowania, jak chciałaby tego władza komunistyczna.

\section{The role of repression apparatus in surveying the state border on the example of Kłodzko Land in 1949-1956}

On the example of Kłodzko Land the author presents one of the fundamental aspects of operations of the repression apparatus in the Stalinist period in Poland, that is the border control. From 1949 on, when the Border Guard was incorporated into the structures of the Ministry of Public Security, and a migration policy was tightened in general, the Ministry began to place a strong emphasis on the security of the state border. It applied both to all the border voivodeships (provinces), and districts. The author has analysed and emphasised several main tasks of the Security Office vis-à-vis a closure of the state border and their protection. He focuses on the presentation of counterintelligence characteristics of the terrain and systematic analyses of the border situation in 1949-1956. He described the organisation and development of the network of agents active on the border, detecting and constant surveillance of persons who wanted to illegally cross the border, liquidation of trafficking channels undertaken by the secret political police, and cooperation with the units of Border Guard and Citizen's Militia. In a concise way he also presented consequences imposed on 
illegal crossers, among other things, on the example of sentences passed by the municipal court at Kłodzko and district court in Wrocław, he described the most frequent verdicts. After an analysis of the documents issued by the Special Commission for the Struggle against Abuses and Economic Sabotage, he answered the question whether the Commission was more repressive in this regard, and imposed more severe punishments. In conclusions, he was able to say whether the border of the Polish state during the Stalinist period was as tight and impossible to force as the communist authorities wanted it to be.

\section{Bibliografia}

Aparat bezpieczeństwa w latach 1944-1956. Taktyka, strategia, metody, cz. 2: Lata 1948-1949, oprac. A. Paczkowski, Warszawa 1996.

Balbus T., Powiatowe i miejskie Urzędy Bezpieczeństwa, w: Urzad Bezpieczeństwa na Dolnym Ślasku 1945-1956. Z badań nad organizacja i działalnościq aparatu bezpieczeństwa. Studia i materiaty IPN, red. R. Klementowski, K. Szwagrzyk, Wrocław 2012, s. 50-94.

Bielecki T., Granice państwowe w systemie prawa państwa socjalistycznego, Warszawa 1972.

Dominiczak H., Granice państwa $i$ ich ochrona na przestrzeni dziejów 966-1996, Warszawa 1997.

Dominiczak H., Powstanie i rozwój organizacyjny Wojsk Ochrony Pogranicza w latach 1945-1983, Warszawa 1984.

Dominiczak H., Wojska Ochrony Pogranicza w latach 1945-1948, Warszawa 1971.

Dominiczak H., Zarys historii Wojsk Ochrony Pogranicza 1945-1985, Warszawa 1985.

Dziki T., Podziały administracyjne Polski w latach 1944-1998. Z badan nad ustrojem ziem polskich $w$ XIX $i$ XX w., „Studia Gdańskie. Wizje i rzeczywistość” 2013, t. X, s. 433-450.

Encyklopedia popularna PWN, wyd. 21 zm. i uzup., Warszawa 1991.

Garlicki A., Z tajnych archiwów, Warszawa 1993.

Grabowski Ł., Maruszak M., Zarys struktur oraz zadania Zwiadu Wojsk Ochrony Pogranicza i Kontroli Ruchu Granicznego w latach 1945-1991, „Pamięć i Sprawiedliwość” 2012, nr 2 (20), s. 311.

Herzig A., Ruchniewicz M., Dzieje Ziemi Kłodzkiej, tłum. V. Grotowicz, Hamburg-Wrocław 2006.

Instrukcje pracy operacyjnej aparatu bezpieczeństwa 1945-1989, oprac. T. Ruzikowski, Warszawa 2004.

Jackiewicz Z., Wojska Ochrony Pogranicza (1945-1991). Krótki informator historyczny, Kętrzyn 1998.

Kamiński Ł., Lingua securitatis, „Pamięć i Sprawiedliwość” 2003, nr 1 (3), s. 209-216.

Klementowski R., Urzad Bezpieczeństwa w powiecie Lwówek Ślaski (1945-1956), Wrocław 2006.

Klementowski R., Zgorzelecka bezpieka 1945-1990, Wrocław 2014.

Komaniecka M., Osobowe źródto informacji w technice operacyjnej, „Aparat Represji w Polsce Ludowej 1944-1989" 2007, nr 5, s. 19-27.

Komisja Specjalna do Walki z Nadużyciami i Szkodnictwem Gospodarczym 1945-1954. Wybór dokumentów, wstęp i oprac. D. Jarosz, T. Wolsza, Warszawa 1995.

Lityński A., O prawie i sadach poczatków Polski Ludowej, Białystok 1999.

Marczak T., Granica zachodnia w polskiej polityce zagranicznej w latach 1944-1950, Wrocław 1995.

Musiał F., Osobowe źródta informacji pionów operacyjnych Stużby Bezpieczeństwa działajacych w granicach PRL, w: Osobowe źródta informacji - zagadnienia metodologiczno-źródtoznawcze, red. F. Musiał, Kraków 2008, s. 27-48.

Musiał F., Zamiast wprowadzenia: archiwalia komunistycznego aparatu represji, w: Wokót teczek bezpieki. Zagadnienia metodologiczno-źródłoznawcze, red. F. Musiał, wyd. 2, Kraków 2015, s. 7-64. 
Nawrocki Z., Struktura aparatu bezpieczeństwa, w: Aparat Bezpieczeństwa w Polsce. Kadra kierownicza, t. I: 1944-1956, red. K. Szwagrzyk, Warszawa 2005, s. 25-48.

Pałys P., Czechosłowackie roszczenia graniczne wobec Polski 1945-1947. Racibórz, Gtubczyce, Kłodzko, Opole 2007.

Prochwicz J.R., Wojska Ochrony Pogranicza 1945-1965. Wybrane problemy, Piotrków Trybunalski 2011.

Sawicki W., Osobowe źródto informacji organów bezpieczeństwa Polski Ludowej, „Aparat Represji w Polsce Ludowej 1944-1989” 2007, nr 5, s. 9-18.

Stownik języka polskiego, oprac. E. Sobol, Warszawa 2005.

Sroka P., Turystyka w polskich Sudetach w latach 1945-1956, Wrocław 2013.

Stola D., Kraj bez wyjścia? Migracje z Polski 1949-1989, Warszawa 2012.

Stola D., O paradoksie masowej emigracji z państwa zamkniętego: wyjazdy do Niemiec $w$ pierwszej połowie lat pięćdziesiatych, w: Władza a społeczeństwo $w$ PRL. Studia historyczne, red. A. Friszke, Warszawa 2003, s. 55-75.

Stola D., Zamknięcie Polski. Zniesienie swobody wyjazdu i uszczelnienie granic w latach 40. i 50., w: PRL. Trwanie i zmiana, red. D. Stola, M. Zaremba, Warszawa 2003, s. 159-186.

Uniszewski Z., Żargon zawodowy pracowników śledczych i operacyjnych. Problematyka kryminalistyczna, Wrocław 1999.

Wygoda J., Zwiad Wojsk Ochrony Pogranicza jako organ bezpieczeństwa państwa w rozumieniu ustawy lustracyjnej, „Aparat Represji w Polsce Ludowej 1944-1989” 2011, nr 8-9, s. $97-116$.

Bi og r a m: Krzysztof Lagojda - historyk, doktorant w Zakładzie Historii Europy Wschodniej Instytutu Historycznego Uniwersytetu Wrocławskiego. Współpracownik Instytutu Pamięci Narodowej. Autor książki Życie w cieniu śmierci. Losy rodzin katyńskich w latach 1939 1989 w świetle wywiadów z członkami Dolnoślaskiej Rodziny Katyńskiej. Wybrane aspekty (Wrocław 2016). Publikował m.in. na łamach takich czasopism, jak „Dzieje Najnowsze”, „Pamięć i Sprawiedliwość”, „Śląski Kwartalnik Historyczny Sobótka”, „Wrocławski Rocznik Historii Mówionej”. Jego zainteresowania badawcze koncentrują się wokół okupacji Polski w czasie II wojny światowej, zbrodni katyńskiej oraz okresu stalinizmu w Polsce. E-mail: krzysztof.lagojda@gmail.com. 